\title{
On the development of a regional climate change adaptation plan: Integrating model-assisted projections and stakeholders' perceptions
}

\author{
Catarina Gonçalves ${ }^{\mathrm{a}, *}$, João P. Honrado ${ }^{\mathrm{b}, \mathrm{c}}$, João Cerejeira ${ }^{\mathrm{a}, \mathrm{d}, \mathrm{e}}$, Rita Sousa ${ }^{\mathrm{a}, \mathrm{d}}$, Paulo M. Fernandes ${ }^{\mathrm{f}}$, \\ Ana Sofia Vaz ${ }^{\text {b,g }}$, Manuela Alves ${ }^{\mathrm{h}}$, Miguel Araújo a , Cláudia Carvalho-Santos ${ }^{\mathrm{b}, \mathrm{i}}$, André Fonseca ${ }^{\mathrm{f}}$, Hélder Fraga ${ }^{\mathrm{f}}$, \\ João F. Gonçalves ${ }^{b, j}$, Angela Lomba ${ }^{b}$, Eva Pinto ${ }^{b}$, Joana R. Vicente ${ }^{b}$, João A. Santos ${ }^{f}$ \\ a School of Economics and Management, University of Minho, 4710-57 Braga, Portugal

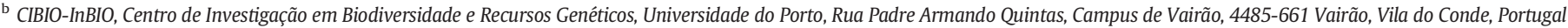 \\ c Departamento de Biologia, Faculdade de Ciências da Universidade do Porto, Rua do Campo Alegre, S/N, Edificio FC4, 4169-007 Porto, Portugal \\ d NIPE Centre for Research in Economics and Management, University of Minho, 4710-57 Braga, Portugal \\ e CIPES Centre for Research in Higher Education Policies, University of Porto, 4450-227 Matosinhos, Portugal \\ ${ }^{\mathrm{f}}$ Centre for the Research and Technology of Agro-environmental Sciences, CITAB, Universidade de Trás-os-Montes e Alto Douro, UTAD, 5000-801 Vila Real, Portugal \\ ${ }^{\mathrm{g}}$ Inter-university Institute for Earth System Research in Andalusia (IISTA), Universidad de Granada, Avda. Del Mediterráneo s/n, 18006 Granada, Spain \\ h Comunidade Intermunicipal do Tâmega e Sousa, 4560-547 Penafiel, Portugal \\ ${ }^{i}$ CBMA Centre of Molecular and Environmental Biology E IB-S Institute for Bio-sustainability, University of Minho, Campus de Gualtar, 4710-57 Braga, Portugal \\ j proMetheus, Research Unit in Materials, Energy and Environment for Sustainability, Polytechnic Institute of Viana do Castelo (IPVC), 4900-347 Viana do Castelo, Portugal
}

\section{H I G H L I G H T S}

- The design of an Action Plan for Climate Change Adaptation is described.

- An increase in temperature and a decrease in precipitation will affect the region.

- Primary and tourism sectors are perceived as the most vulnerable.

- Scientific and local knowledge is crucial for successful adaptation planning.

\section{A R T I C L E I N F O}

\section{Article history:}

Received 8 March 2021

Received in revised form 2 July 2021

Accepted 9 September 2021

Available online 14 September 2021

Editor: Manuel Esteban Lucas-Borja

\section{Keywords:}

Adaptation planning

Water resources

Agriculture and forestry
G R A P H I C A L A B S T R A C T

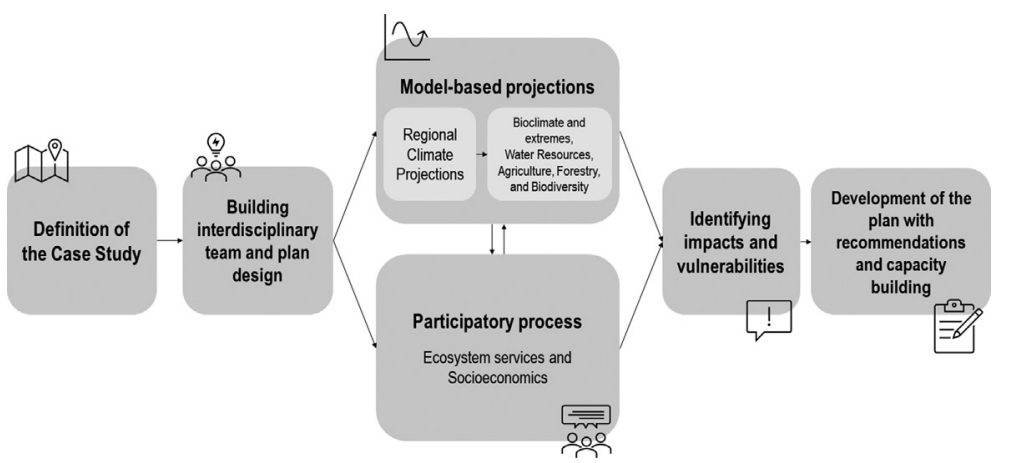

\section{A B S T R A C T}

Climate change is expected to have strong social-ecological implications, with global but especially regional and local challenges. To assess the climatic vulnerability of a given territory, it is necessary to evaluate its exposure to climate change and its adaptive capacity. This study describes the development of an Action Plan for Adapting to Climate Change in the Tâmega and Sousa Region, a mountainous inter-municipal community in the North of Portugal. The goals were to identify the main impacts of climate change on water resources, agriculture, forests, biodiversity, and socioeconomic sectors, as well as to develop a plan, merging local and scientific knowledge through a transdisciplinary lens. This study describes an approach that combines modelling methods, applied in the different sectors, and participatory methods, based on the analysis of the perceptions of local actors. Results indicate that the target region will experience a generalized increase in temperature and a decrease in precipitation, which will negatively impact all studied social-ecological dimensions. Overall, local business and institutional agents perceive the primary and tourism sectors as the most vulnerable in the region. The described framework demonstrates the engagement process between relevant scientific experts and local practitioners, as well as how it is critical to understand the impacts of climate change and to support the co-design of an

\footnotetext{
* Corresponding author.

E-mail address: d8243@eeg.uminho.pt (C. Gonçalves).
} 
Biodiversity

Socioeconomics adaptation plan, which in turn can guide political and economic decision-making towards effective implementation of the plan. In addition, the difficulties and challenges encountered during this process are discussed to support future plans and strategies for local adaptation.

(c) 2021 Elsevier B.V. All rights reserved.

\section{Introduction}

In recent decades, climate change has affected a wide range of natural and human systems worldwide. Several studies in southern Europe showed that climate change has noteworthy economic and socioecological implications (IPCC, 2014a), such as an expected decrease in water availability (Fonseca and Santos, 2019; Fraga et al., 2020b), an overall reduction in crop productivity (IPCC, 2014a), increased wildfire activity (Dupuy et al., 2020), higher risk of species extinctions (Araújo et al., 2011), and increased spread of alien invasive species (Vicente et al., 2013).

To reduce and manage climate change impacts, it is fundamental to assess the vulnerability of a territory and its communities, which depends not only on its exposure to climate change, but also on the adaptive capacity of the different sectors and the local socioeconomic context (IPCC, 2014b). This assessment involves the use of databases and methods that must be applied in each context. Nevertheless, the lack or low quality of input data (e.g., low spatial resolution), along with the paucity of adequate structures for data sharing, often are limiting factors. Moreover, uncertainties related to climate and socioeconomic patterns in the future further constrain the predictions of climate change impacts (Beck et al., 2014; Mukheibir et al., 2013). Despite these challenges, modelling techniques are useful to understand and predict climatic variability and extreme events, such as droughts and heatwaves. Climate change projections are based on data generated by Global Climate Models (GCMs) - Regional Climate Models (RCM) chain simulations. These data can be further downscaled using e.g. geostatistical techniques, which is a procedure frequently used in different research fields that allows supporting decision-making at finer scales (Fonseca and Santos, 2018; Fraga et al., 2020c).

The use of a transdisciplinary approach that not only depends on predictive modelling procedures, but also accounts for the knowledge and perceptions of local stakeholders and communities, benefits adaptation planning (Pohl, 2005). Multidisciplinary teams of natural and social scientists are key to tackle local challenges regarding climate change adaptation. Transdisciplinarity is indeed advocated by several authors due to the inherent complexity of climate change issues and the possibility of welcoming the interests of different sectors and stakeholders (Huggel et al., 2015; Ker Rault et al., 2019; Lemieux et al., 2014; Pittman et al., 2011; Pohl, 2005).

The engagement of political decision-makers in these processes is also essential, since the implementation of concerted and effective adaptation measures requires economic and political decision-making in a multilevel governance framework (Amundsen et al., 2010). Local stakeholder's perceptions, in particular on climate change at the municipality scale, can be highly valuable to understand to what extent they are concerned and able to support policy implementation (Campos et al., 2017; Hagen et al., 2016).

Recently, studies on local climate change adaptation have been developed to support the design of action plans and strategies (Aguiar et al., 2018; Amundsen et al., 2010; Coelho et al., 2020; Dannevig et al., 2012). In Portugal, the ClimAdaPT.Local project (www.adaptlocal.pt) supported the development of 26 local climate change adaptation strategies, involving the training of municipal technicians and local community engagement, alongside fostering the integration of adaptation strategies into local governance (Schmidt et al., 2018).

This study describes the development of a multidisciplinary, modelassisted, climate change adaptation plan specifically tailored for the
Intermunicipal Community of Tâmega and Sousa (CIM-TS), in Northern Portugal, named Intermunicipal Plan for Adaptation to Climate Change in Tâmega and Sousa region (PIAAC-TS). PIAAC-TS has been projected in the CIM-TS "Pact for Development and Territorial Cohesion" so as to contribute towards the implementation of the National Climate Change Strategy under the Operational Program for Sustainability and Efficiency in the Use of Resources (PO SEUR).Specifically, the team in charge of developing PIAAC-TS aimed to analyse the main potential impacts of climate change on the different socioeconomic and environmental sectors of a mountainous inter-municipal community, grounded on quantitative and spatially explicit predictive models whenever possible. The approach explored the integration of scientific and local stakeholder knowledge into the design of a support tool for decisionmaking, envisioning climate change adaptation. This region was selected from the convergence of two factors. First, it was interesting for the team to study this theme at this scale from a scientific point of view. The three organizations involved in this study have done previous research in the area and have thus a solid knowledge on the territorial social-ecological dynamics. Furthermore, taking into account the extended region, the team recognizes this territory, rich in ecological and social values, as particularly interesting to test the application of the methodologies developed and the connection with stakeholders. On the other hand, this study was requested by the local actors themselves, responsible for managing the territory at the CIM-TS level, who are aware of the impacts that climate change may have on the region, recognising the need to develop an adaptation plan.

This article is organized as follows. Section 2 describes the case study of the CIM-TS and the context in which the study was carried out. Section 3 explains the methodological approach to develop an adaptation plan for decision-making. The results of predictive models and the perception of local actors on climate change are presented in Section 4. Section 5 presents a critical analysis of the results, comparing with previous studies, identifies some limitations of the approach, and presents the main conclusions.

\section{The Intermunicipal Community of Tâmega and Sousa}

\subsection{Geographic and environmental setting}

Following the Nomenclature of Territorial Units for Statistics (NUTS; Eurostat, 2018), a hierarchical system for dividing the territory into regions according to geographical, administrative and populational criteria, CIM-TS is a Level 3 region (NUTS III), being a part of the North Region (NUTS II) of Mainland Portugal (NUTS I). The CIM-TS includes 11 municipalities: Amarante, Baião, Castelo de Paiva, Celorico de Basto, Cinfães, Felgueiras, Lousada, Marco de Canaveses, Paços de Ferreira, Penafiel and Resende (Fig. 1). The legal representatives of the CIM-TS are chosen based on political appointment by the different municipalities.

From a geographical point of view, the CIM-TS is crossed by the Douro river in its southernmost municipalities, by the Tâmega river with a northeast-southwest orientation, and by the Sousa river in the western area. Orography is complex and marked by a mountainous area in the eastern part, but most of the territory is below an elevation of $500 \mathrm{~m}$. Regarding land cover, $52 \%$ of the territory is classified as forest or semi-natural areas, $41 \%$ as agricultural areas, $6 \%$ as artificial surfaces, and $1 \%$ corresponds to watercourses or water surfaces. The CIM-TS includes three classified areas in the Natura 2000 network. The region 


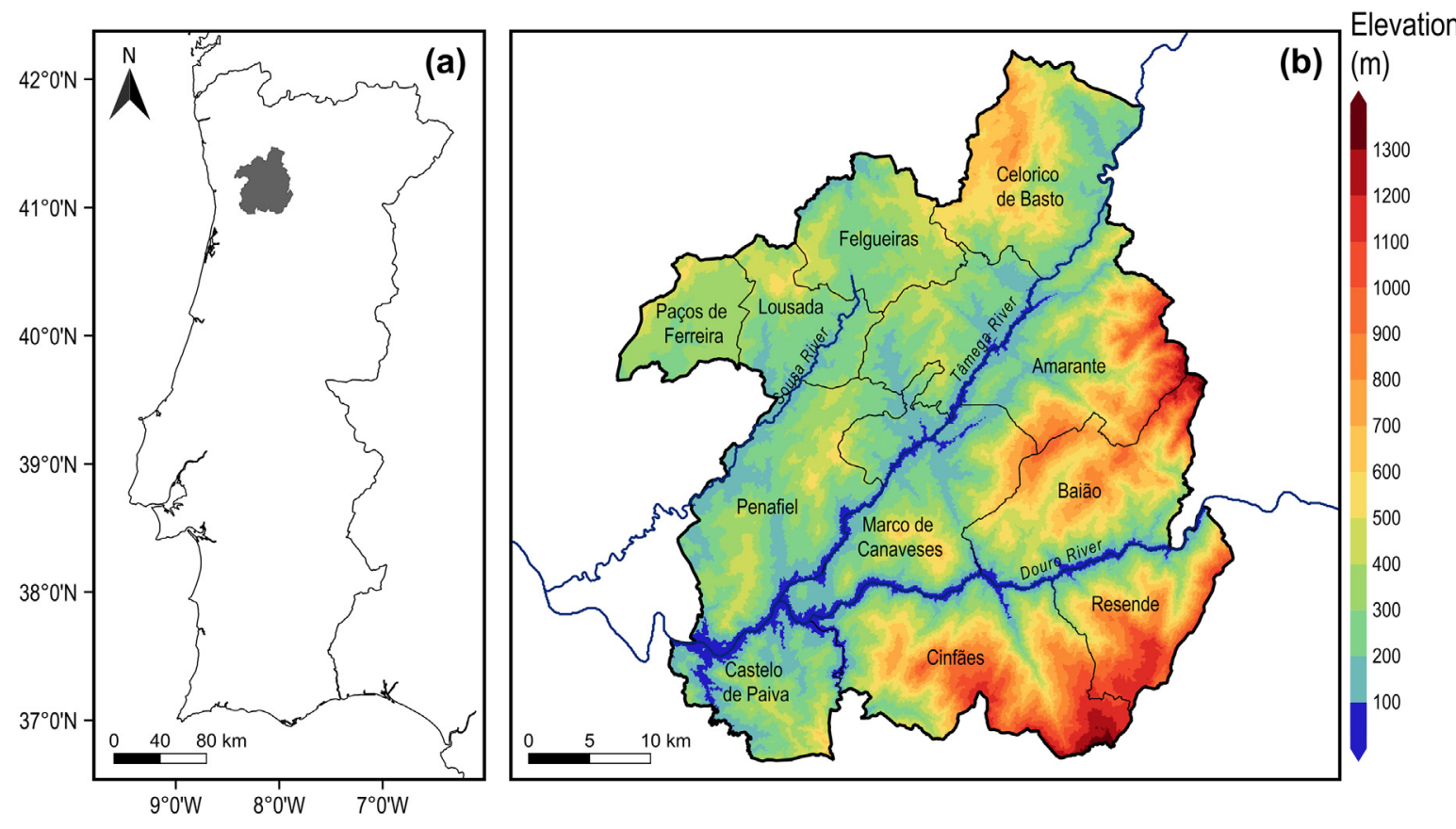

Fig. 1. (a) Geographical location of the CIM-TS in mainland Portugal and (b) hypsometric chart of the region, along with the municipalities and their corresponding borders.

features a warm temperate Mediterranean-type climate, though with a marked maritime influence, with typically mild rainy winters and warm dry summers.

\subsection{Socioeconomy and governance}

The CIM-TS has an area of $1832 \mathrm{~km}^{2}$, corresponding to about $8.6 \%$ of the Northern Region of Portugal and $2 \%$ of the country (PORDATA, 2019). It has nearly 430,000 inhabitants, which corresponds to about $4 \%$ of the resident population in Portugal. Population density is more than twice the national average (236 vs. 112 inhabitants $\mathrm{km}^{-2}$ ) (PORDATA, 2011). Following the 2011-2013 national economic crisis, the region has seen a population decrease (INE, 2018a). The education level of the adult population is lower than the national average, although converging in recent years as young cohorts show higher schooling levels (INE, 2018b).

The region has the lowest GDP (Gross Domestic Product) per capita in the country (63\% PT), although in recent years it has grown more rapidly. Concerning the main sectors of the economy, namely primary sector (related to raw materials such as agriculture), secondary sector (concerned with finished goods such as manufacturing, utilities and construction) and tertiary sector (concerned with services such as retail and tourism), the municipalities can be clustered into two groups. The first group (south and east municipalities) includes rural areas with low population density and the greatest population aging, where the agricultural sector is still relevant, namely the wine sector with the highest growth. Tourism activities in these municipalities expanded recently, benefiting from environmental amenities (e.g. landscape and biodiversity). The second group includes municipalities on the western part of the territory and tends to be more specialized in the secondary sector or services. Construction activities and export-driven manufacturing activities, such as textile, clothing, leather, footwear and furniture, are the main activities, with specialization growing in recent years (INE, 2019).

Policy-wise, the PIAAC-TS is a regional instrument, under the National Strategy for Adaptation to Climate Change 2020 (Resolution of the Council of Ministers nr. 56/2015). This Strategy includes and articulates several management and planning instruments at multiple scales and across different socioeconomic sectors. Examples of such instruments are the Land Use Planning for Northern Territory, coordinated by the Northern Regional Development Coordination Commission; the Douro River Basin Management Plan, managed by the Portuguese Environment Agency; the Natura 2000 Network and the Regional Forest Management Plan of Entre Douro e Minho, overseen by the Institute for the Conservation of Nature and Forests; and local scale land-use and urban planning instruments coordinated by local administrative entities.

\section{Approach and methods}

\subsection{Designing a plan for climate change adaptation}

The design of PIAAC-TS followed five main steps (Fig. 2) that are subsequently described. Overall, the methodology includes approaches based on modelling the environmental system and on understanding local actors' perceptions, not only on climate-related aspects, but also on the potential impacts of climate change in different economic activities and on the territory. The outcomes of this process supported the PIAAC-TS design, which has been the target of several dissemination and training activities.

\subsubsection{Step 1 - setting the scene}

A multidisciplinary team was constituted in the first step. Initial meetings with the scientific team and members of the CIM-TS allowed defining the coordinators, the methodology, the objectives, and the intended results. The main territory stakeholders, at different levels of decision, were also identified in this phase (municipalities and CIM$\mathrm{TS}$, local associations, and economic sector representatives).

The ecological, socioeconomic, and environmental sectors that would be most exposed and vulnerable to climate change were identified based on multiple discussions. These thematic sectors included water resources, agriculture and forestry, biodiversity, ecosystem services, and several socioeconomic sectors (see Section 3.2).

Data on meteorology, water flows, wildfires, species occurrence, and socioeconomics statistics were collected through literature surveys and existing databases for all technical-scientific studies, complemented by 


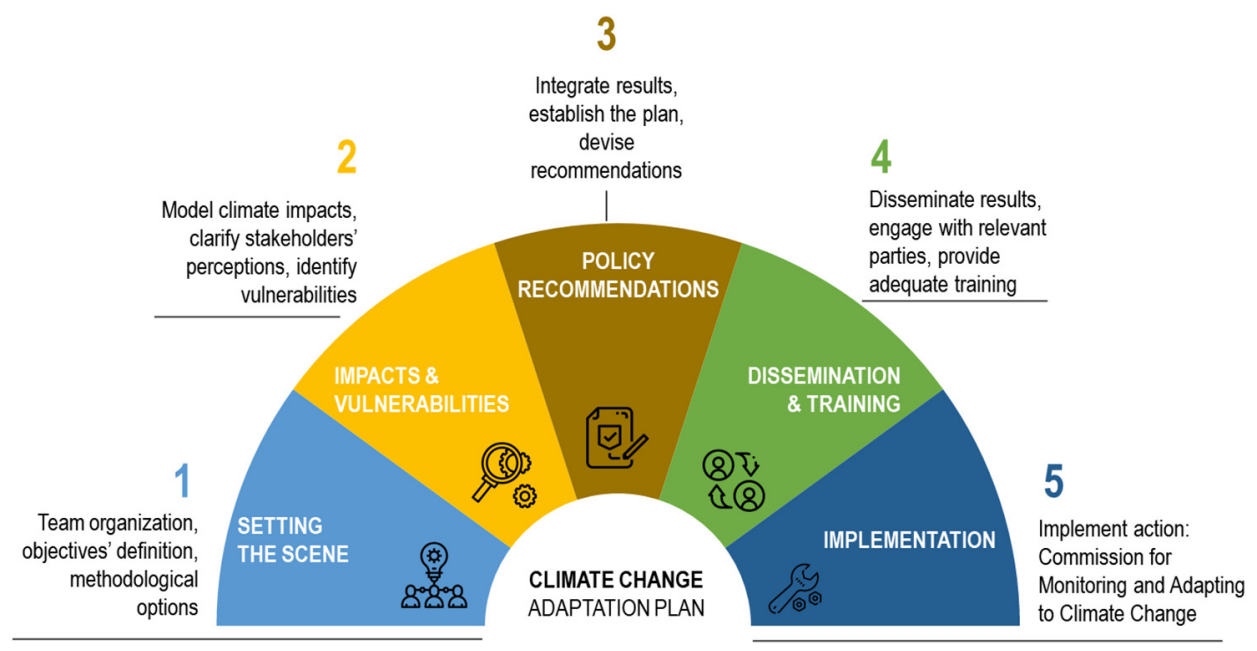

Fig. 2. Workflow diagram showing the development of the Climate Change Adaptation Planning Process.

information provided by public and/or private local, regional and national agencies.

\subsubsection{Step 2 - identifying potential impacts and vulnerabilities}

The focus of the second step was on analysing the expected impacts of climate change in the territory. To do so, a series of modelling techniques were adopted to understand the putative effects of climate change on water resources (Section 3.2.2), agriculture and forestry (Section 3.2.3), and biodiversity (Section 3.2.3). State-of-the-art scenarios of climate change supported these modelling techniques (Section 3.2.1). Social-based approaches to understand the perceptions of multiple stakeholders on the effects of climate change on ecosystem services (Section 3.2.4) and economic activity (Section 3.2.5) were subsequently used.

\subsubsection{Step 3 - development of the adaptation plan with the main recom- mendations}

Based on scientific studies and adaptation proposals by local agents gathered during the follow-up meetings with technicians from the CIM-TS and the various thematic workshops held, the main adaptation challenges were identified. Based on these challenges, a set of recommendations on adaptation measures were suggested by the multidisciplinary team, as well as strategic guidelines looking to implement the PIAAC-TS. These recommendations are intended to support decision making in adapting and managing the impacts of climate change on the territory. To this end, it is hoped that they can be converted into concrete action measures.

\subsubsection{Steps 4 and 5 - dissemination and implementation}

Developing the PIAAC-TS included actions of training and dissemination of results across the territory. In this regard, 12 training sessions were held by the research team targeting local institutional and economic agents, to increase their capacity to integrate adaptation actions into decision-making processes. In addition, 11 dissemination sessions of the PIAAC-TSs results were held for the local community to raise awareness about climate change issues to generate behavioural change and to strengthen public involvement and participation in the future implementation of the plan.

\subsection{Methods}

\subsubsection{Climate change scenarios}

All technical and scientific analyses undertaken in this study were based on a set of fundamental atmospheric variables: daily minimum, mean and maximum temperatures at $2 \mathrm{~m}$ above the ground, total daily precipitation, daily mean relative humidity at $2 \mathrm{~m}$ above the ground, and daily mean wind speed at $10 \mathrm{~m}$ above the ground. A comparative analysis was carried out between the current (historical period: from 1981 to 2010) and the future climate projections (future period: 2041 to 2070), according to the IPCC Representative Concentration Pathway (RCP) 4.5 scenario.

This period was chosen because it is the one usually used for medium-term planning. The long-term period (2071-2100) is too far away for many decision-makers and politicians in the territory. This period was considered to be the most appropriate for strategy and adaptation planning. Moreover, the uncertainties in the long-term period are much higher. Among the different RCPs (Moss et al., 2010), RCP4.5 is more aligned with the current global policies, though still surpassing the target of the Paris Agreements, which aims at limiting the rise in global average near-surface temperature below $1.5-2{ }^{\circ} \mathrm{C}$ above preindustrial levels (IPCC, 2014c, 2018). RCP4.5 can be considered as a trade-off between the higher-emission scenarios RCP8.5 or RCP6.0 and the too optimistic low-emission scenario RCP2.6.

The climatic projections of the fundamental variables were based on a 5-member ensemble (pairs of regional models coupled with global climate models), which allowed a significant reduction in scale (dynamic downscaling) to about $12 \mathrm{~km}$. The application of complementary methodologies allowed to increase spatial resolution to $1 \mathrm{~km}$ (statistical downscaling). In regions with scarce and climatically heterogeneous meteorological information, as is the case of the territory under study, the climatic projections are commonly produced by the application of the "delta" method. All selected models and simulations were based on projections developed in previous studies (Fonseca and Santos, 2019; Santos et al., 2019a).

The relative humidity and wind intensity were retrieved from the ERA5 reanalysis dataset, produced by the ECMWF (European Centre for Medium-range Weather Forecast). In this case, points were extracted from the original ERA5 grid, thus avoiding uncertainties associated with the different interpolation approaches.

\subsubsection{Water resources}

The Better Assessment Science Integrating Point and Nonpoint Sources (BASINS) model was used, developed by the Environmental Protection Agency of the USA for local and regional agencies and governments responsible for managing water resources. The main tool for modelling water quality and quantity was the Hydrological Simulation Program (HSPF) (Bicknell et al., 2001).

BASINS is an open-source framework that couples modelling tools and environmental spatial data into a geographic information system (GIS) interface. BASINS can be used for on a variety of geospatial scales 
from small watersheds within a single municipality, to a large watershed across several municipalities. The HSPF component is a semidistributed model that performs the hydrologic calibration of any catchment. As only one hydrometric station was available with continuous data there was no need to resort to a fully distributed model which requires high-level computation and time-dependent mode.

The parameterization for calibrating this model was carried out with the CORINE Land Cover 2012, a 10-m resolution digital terrain model and the respective climate data for the period under study. The calibration and validation was performed for Tâmega and Sousa catchments, two main tributaries of Douro River. The HSPF model was not computed for Douro River due to its extension and the existence of many dams and levees, which artificialize the flow rate. Further, the calibration of Douro River does not impact the performance of the model in the two catchments. The daily mean flows for the entire period of 1950-2015 were simulated and computed, as well as the corresponding return periods (10,20, and 50 years) associated with extreme flow events.

\subsubsection{Agriculture and forestry}

Bioclimatic indices are commonly used in the bioclimatic zoning of various crops and forest species (Costa et al., 2017; Fraga et al., 2017, 2019; Santos et al., 2019b). In the present study, several bioclimatic indices were calculated, namely the extreme indices from the ETCCDI Expert Team on Climate Change Detection and Indices (Karl et al., 1999), bioclimatic indices more devoted to viticulture, e.g., Huglin, Dryness, Branas, and Cool Night Indices (Fraga et al., 2017), and indices for chilling and forcing (Chilling Portions and Growing Degree Hours) that are of much broader use for several crops, such as temperature fruit trees (Fraga et al., 2019). Nonetheless, due to the importance of viticulture in the region (Fraga et al., 2017), and the availability of historical crop data for calibration, this crop was studied in more detail using the STICS model, developed at INRAE (French National Research Institute for Agriculture, Food and the Environment), and recently developed to integrate a grapevine simulation module. This model was previously calibrated and validated by the project team (Fraga et al., 2020a, Fraga et al., 2015).

Seven sites located in representative forest areas were selected to assess the potential climate change impacts on wildfire activity. Daily meteorological data for these sites, for both the historical and future periods, were extracted from the aforementioned gridded datasets (Section 3.2.1). Indices of the Canadian Forest Fire Weather System (FWI) (Stocks et al., 1989), officially adopted in Portugal for fire danger rating were calculated, as well as their corresponding statistical descriptors. The corresponding fire spread rate and fireline intensity were simulated with the BehavePlus software (Andrews, 2014). The burnt area was modelled by non-linear regression from FWI codes and historical cumulative burnt area.

\subsubsection{Biodiversity}

Species Distribution Models were applied to project the effects of climate change on the spatial distribution of targeted species (including both native taxa with conservation status and invasive alien species) and to infer their suitable habitat conditions under future climate. The models were developed in R statistical software using the biomod2 package which combines multiple modelling algorithms in an ensemble consensus approach. Using the same $\mathrm{R}$ package, the environmental variables importance was calculated for the consensus models. This package and modelling approach are presented in Thuiller et al. (2009, 2014). The modelling framework was previously applied by team members/authors in previous research, e.g., Gonçalves et al. (2016).

These analyses allowed assessing, following a quantitative and spatially-explicitly approach, which species, taxonomic groups, and areas of the territory are potentially more sensitive to climatic fluctuations predicted by the projected climatic scenarios.

\subsubsection{Ecosystem services}

According to the Millennium Ecosystem Assessment and the International Common Classification of Ecosystem Services classifications (Appendix A), three main types of ecosystem services were recognised: provisioning, as the material outputs from ecosystems (e.g. food, wood); regulating, as the results from regulatory and maintenance processes and functions from ecosystems (e.g. soil maintenance, pest control); and cultural, as the non-material benefits that result from psychological (e.g. aesthetics) and physical (e.g. recreation) interactions of humans with nature.

Given the anthropocentric nature of the concept of ecosystem services, we used participatory and deliberative approaches to understand how local managers perceive the impacts of multiple climate change determinants and how they expect to be exposed to those impacts. Specifically, two workshops were organized with 22 stakeholders ( 12 women and 10 men), including senior technicians, coordinators, and heads of division in the sector of environment or land-use planning, representative of each municipality. The workshops were moderated by the research team and engaged the stakeholders in deliberative discussions and participatory questionnaires to identify the most valued ecosystem services in the study region and the expected effects of climate change.

\subsubsection{Socioeconomics}

To analyse the socioeconomic aspects of climate change adaptation, the first step consisted of a characterization of the region. The main two themes of this characterization were "human capital and knowledge" and "economic resources".

A survey was carried out in the first quarter of 2019, sent to 55 organizations, to describe the sensitivity of each of the sectors and the relevant dimensions to the adaptability analysis of the region and the impacts of climate change in economic activity. Additionally, five workshops were held between April and May 2019, organized for 78 relevant business and institutional agents in the territory. The use of these analytical instruments aimed, firstly, at investigating and assessing the respondents' perceptions of climate change, namely regarding the degree and quality of the available information on the risks and potential effects of climate change. Secondly, the goal was to evaluate the economic impacts, based on the future climatic scenarios elaborated for the Tâmega and Sousa region, in terms of "production costs", "sales volume", and the "use of more advanced technologies that reduce negative impacts or expand positive effects of climate change". The questionnaire was the starting point of vulnerability and adaptation analyses.

\section{Results}

\subsection{Model-assisted projections}

\subsubsection{Climate change}

Heatwaves will be more frequent and intense and frost days less frequent. Due to the decrease in precipitation during summer, droughts may be more intense and frequent. However, the territory is highly heterogeneous and, therefore, an in-depth analysis is required for specific locations (Fig. 3).

\subsubsection{Water resources}

The hydrological modelling of the Sousa and Tâmega basins indicates a global reduction in water availability, and thus a decrease in the soil water content and the availability of water for irrigation during the summer period (Appendix B).

\subsubsection{Agriculture and forestry}

Bioclimatic indices indicate a significant increase in the thermal forcing of the various crops, which may significantly anticipate different phenological states and development stages of some crops. However, the absence or insufficiency of dormant conditions in the future may jeopardize the economic viability of various crops, namely fruit plants. 

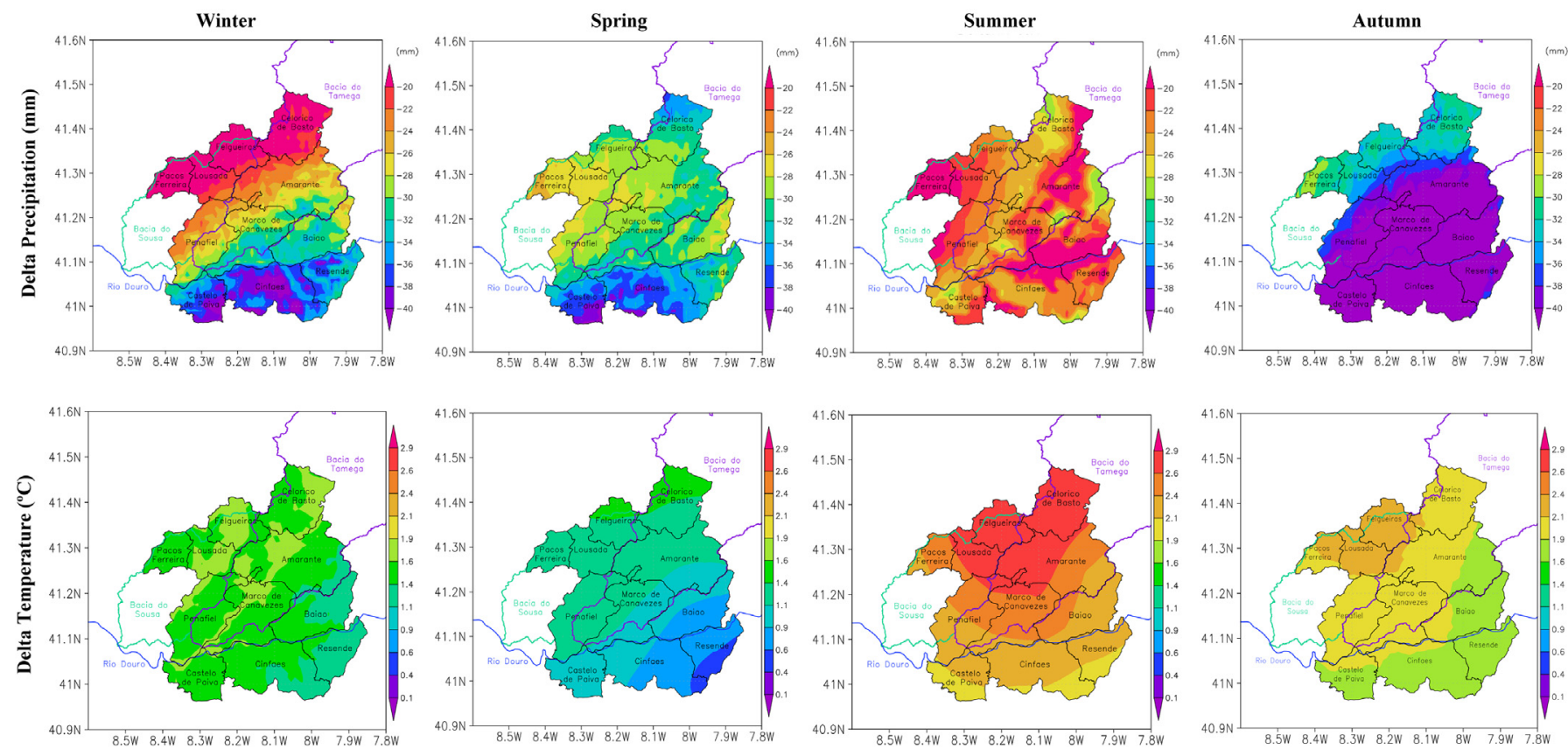

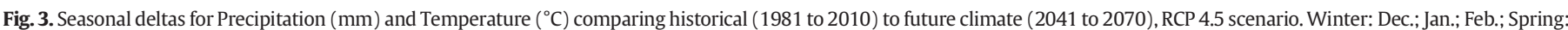
Mar.; Apr.; May; Summer: Jun.; Jul.; Aug.; Autumn: Sep.; Oct.; Nov.

In the particular case of viticulture, projections indicate that conditions will in general be adequate in the future.

In the forestry sector, the results of predictive models reveal a worsening of fire weather conditions, particularly in the summer months. The annual average burnt area can triple as a result.

\subsubsection{Biodiversity}

A general decrease in the area climatically suitable for flora and fauna with conservation status was predicted (Fig. 4b; Fig. C1b - Appendix C). However, in some locations, like the mountain regions of the southeast, many of the studied species are expected to maintain climatic suitability thus highlighting the relevance of these ecosystems for biodiversity adaptation and conservation (Fig. 4a; Fig. C1a - Appendix C).

Overall, precipitation variables presented the highest importance for explaining the distribution of native plant species, with the Precipitation of the Wettest Month (BIO_13) being the most important (Fig. 5). The same variable was also the first or second most important in explaining and predicting the distribution of all fauna species studied, emphasizing its relevance across all groups (Fig. C2 - Appendix C).

In fact, comparing Figs. $4 \mathrm{~b}$ and 3 , it is possible to identify a spatial overlap between the locations where several flora species with conservation status will lose climate suitability (in specific, the southeast part of the region) and the locations where a reduction in precipitation is projected, especially in the winter. Therefore, it is expected that a decrease in winter precipitation (drier conditions) will be a major contributor to the decrease in suitable conditions for native plant species in these areas (Table C1 - Appendix C).

As for invasive alien species, the predictive models indicate that most of the selected species already have climatically suitable areas within most of the territory. Overall, the amount of this climatically suitable area is predicted to remain stable (Fig. 4c) and few are the locations where it's expected to decrease (Fig. 4d). The species Acacia longifolia stands out due to its increase in potential area. In contrast, future projections indicate a potential reduction in the suitable area for the species Vespa velutina (Asian hornet currently affecting honey bee colonies in the country). Still, predictive models could be biased by the fact that the species is a recently introduced invader in the country (Gallien et al., 2012).

\subsection{Stakeholders' perceptions}

\subsubsection{Ecosystem services}

Different determinants were perceived to affect different types of ecosystem services in different ways. The stakeholders particularly emphasized heatwaves, droughts, diseases and pests, and invasive alien species. Wildfires were perceived as the most relevant determinant, potentially impacting the three types of services (i.e. provisioning, regulating, and cultural).

In general, climatic impacts of most determinants on the various ecosystem services assessed were perceived as medium to high and were expected to stabilize or increase in the future. Regulation ecosystem services were perceived by stakeholders as the most vulnerable. Conversely, recreational activities were perceived to be promoted by heatwaves in the future.

\subsubsection{Socioeconomics}

Perceptions about the level of knowledge regarding climate change impacts reveal these are perceived at national and global levels rather than at the local level. Sectorially, the respondents' perceptions reveal that the actors working in the primary sector know more about the impact of climate change than those who work in tourism-related activities and the secondary sector.

Stakeholders' awareness of climate change and its economic impact indicates that the primary and tourism sectors are the most vulnerable, although heterogeneously in the territory. The primary sector is the one where the effects of climate change are most noticeable, particularly in terms of production costs affected by energy costs and demographic factors. The respondents' perception is that production costs in the tourism sector may increase due to a higher incidence of forest fires and an increase in energy costs (Fig. 6).

Concerning the tertiary sector, future growth in the health and social support sectors is expected, resulting from demographic aging. The impacts of climate change on the secondary sector are overall less perceived by respondents. 
Flora species with conservation status that mantain climate suitability

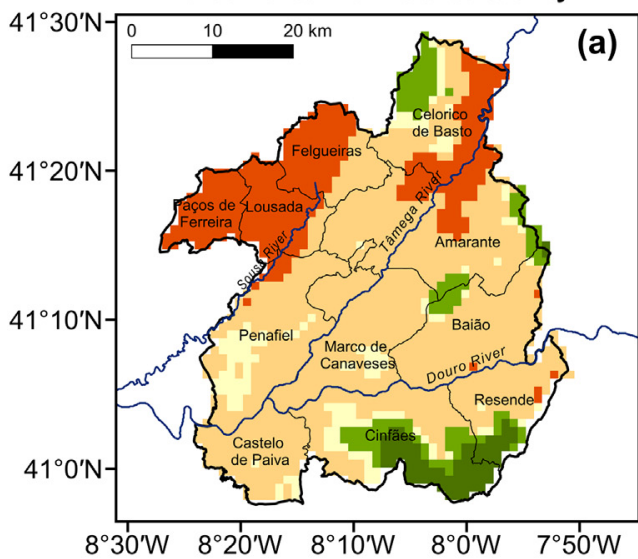

Number of species

0-1 (Greatest potential negative effect)

1-2

3-4

5-7

8-10 (Least potential negative effect)

Invasive species that mantain climate suitability

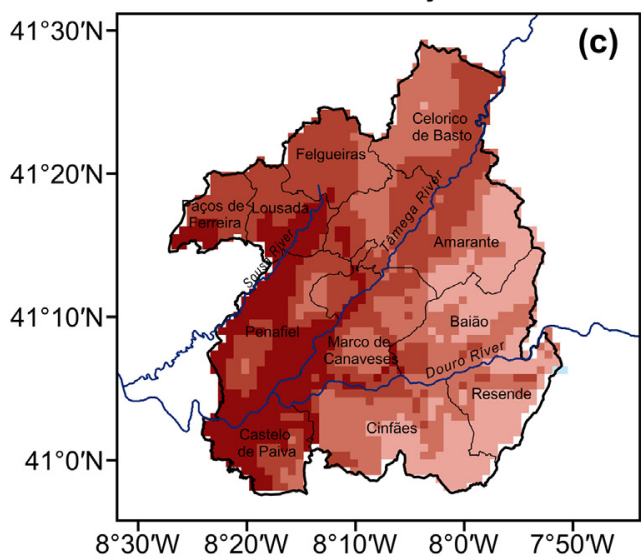

Number of species

$\square$ (Least potential negative effect)
1 - 3
3 - 5
5 - 6
6 - 8 (Greatest potential negative effect)

Flora species with conservation status that lose climate suitability

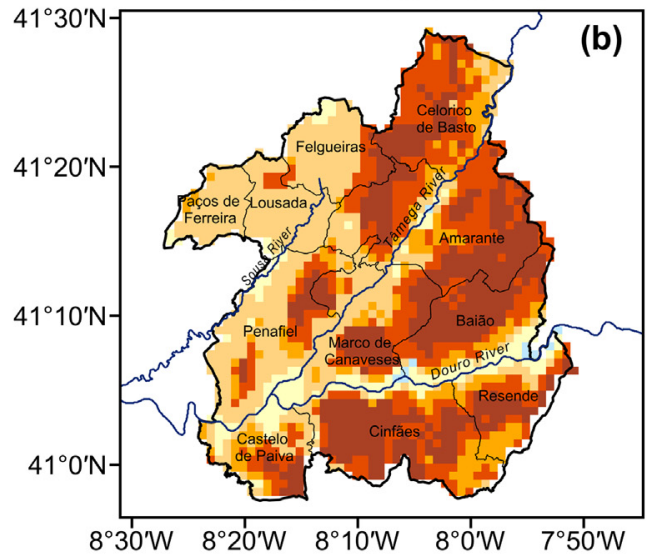

Number of species

0 (Least potential negative effect)

1-3

$\square-5$

$6-6$

7-8

9-11 (Greatest potential negative effect)

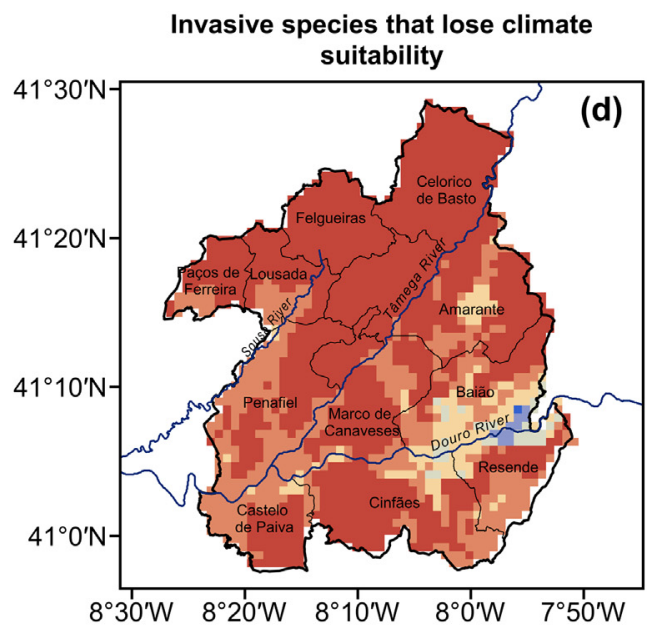

Number of species
0 (Greatest potential negative effect)
1
2
3
4
5 (Least potential negative effect)

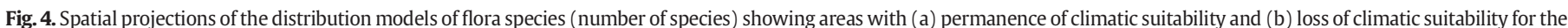

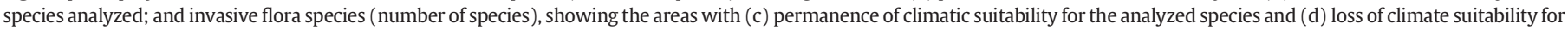
the invasive species analyzed.

\subsection{Synthesis of vulnerabilities and adaptation plan}

At this stage, the project team gathered and integrated all the evidence and projections resulting from the various scientific studies and identified specific recommendations for each sector under assessment to support decision-makers and policymakers (Table 1 ). An extended version of the recommendations developed by the scientific team is presented in Appendix D.

Translating the recommendations (Table 1 ) into concrete adaptation actions is a critical step to entail by the municipalities. Thus, the multidisciplinary team suggested the creation of a Commission for Climate Change Monitoring and Adaptation in the CIM-TS formed by three main sectorial groups operating at the inter-municipal level to manage and continuously monitor the adaptation actions (Fig. 7). This Commission organigram should incorporate technicians from the CIMTS and the associated municipalities, as well as local organizations and agents involved in managing water resources, agriculture, forest, environment, energy and human health, in addition to companies with high socioeconomic value in the region. Sectorial groups must involve organizations with responsibilities and interests in the 


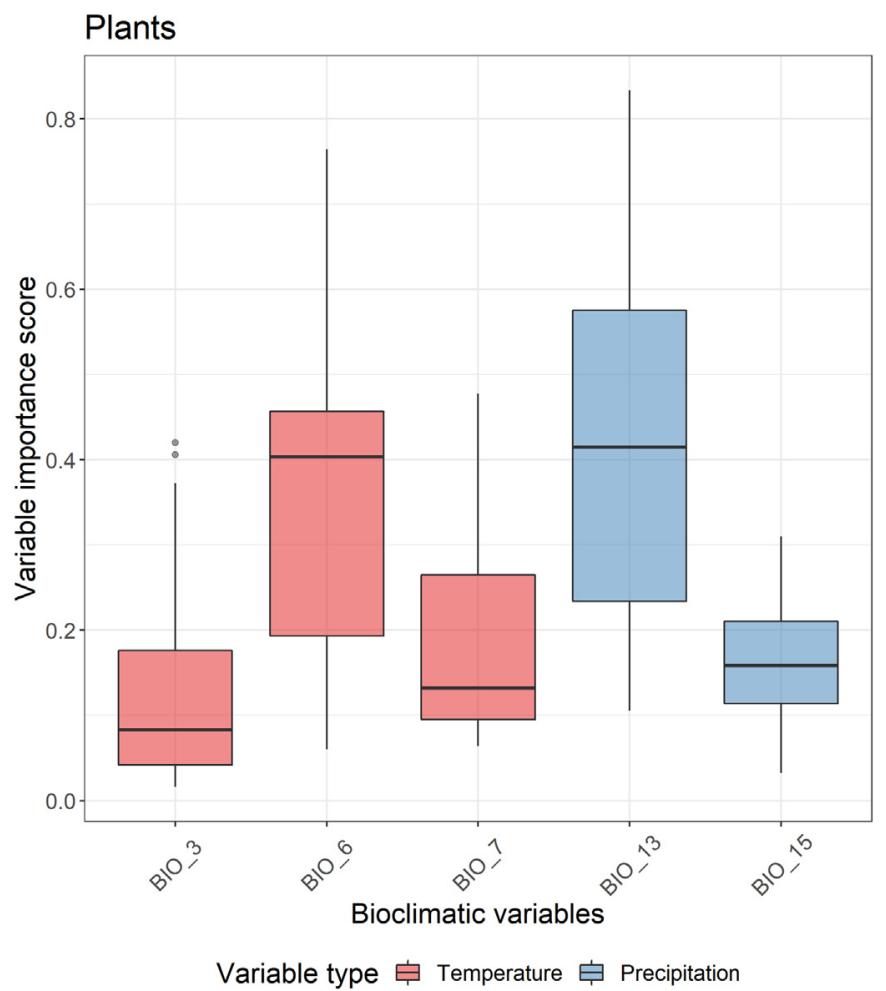

Fig. 5. Boxplot representing the distribution of importance scores for predictive bioclimatic variables used to model native plant species distributions. BIO_03 Temperature Isothermality, BIO_6 - Minimum Temperature of the Coldest Month, BIO_7 - Temperature Annual Range, BIO_13 - Precipitation of the Wettest Month, and BIO_15 - Precipitation Seasonality (Coefficient of Variation).

respective sectors of the territory and, if possible, in neighbouring territories. These groups must define medium- to long-term action plans and continuously monitor the progress of their implementation. This transdisciplinary Commission should be responsible for managing the implementation and monitoring of the different adaptation measures, for facilitating the participation and interaction between the various stakeholders and resolving potential cross-sectorial conflicts that may arise between proposals.
In the final phase of the study the multidisciplinary team made an integrative exercise, to assess the positive and negative cross sectoral effects of the different adaptation measures, for example, what impact actions focused on mitigating the effects of climate change on agriculture could have on other sectors? This exercise systematizes the results obtained, taking into account the perceptions of the various specialists in the team. This was a collaborative work, revised together, which culminated in the construction of a table which is presented in the Appendix E.

\section{Discussion and conclusions}

This study identified the main impacts of climate change in a mountainous inter-municipal region in Portugal and proposes a set-wise approach to create a regional climate change adaptation plan based on biophysical, socioeconomic, and climatic data.

\subsection{Impacts and vulnerabilities}

The project team applied several models to evaluate regional exposure to climate change. Previous studies by the project team had already applied the downscaling methodology for climate projections (Fonseca and Santos, 2018.) However, the present work allowed an unprecedented level of regional detail. In addition to the scientific evaluation based on modelling, the analysis of stakeholder perceptions was also used to gather insights and capture the local knowledge from agents.

The generalized increase in temperature and decrease in precipitation is in line with previous studies for northern Portugal (Andrade et al., 2014; Santos et al., 2019a). These climate variations may have serious consequences for several systems and sectors, such as water, agricultural and forest resources, biodiversity, human health, and socioeconomic agents. Extreme events, such as heatwaves and the occurrence of droughts are important aspects to consider since they can trigger or amplify many other extreme situations, namely wildfires (Fernandes et al., 2016), or crop damages (Fraga et al., 2020a).

Regarding water resources, a gradual increase in dryness and scarcity is expected, as reported in previous studies (Fonseca and Santos, 2019). This may lead to increased water use conflicts (Fraga et al., 2020c), which will require an accurate assessment of the adaptive capacity of each consumer sector (e.g., agriculture, industry, energy and municipal) (Whitehead et al., 2019). However, the agricultural sector is likely to be one of the sectors most affected by the scarcity of water
Agriculture

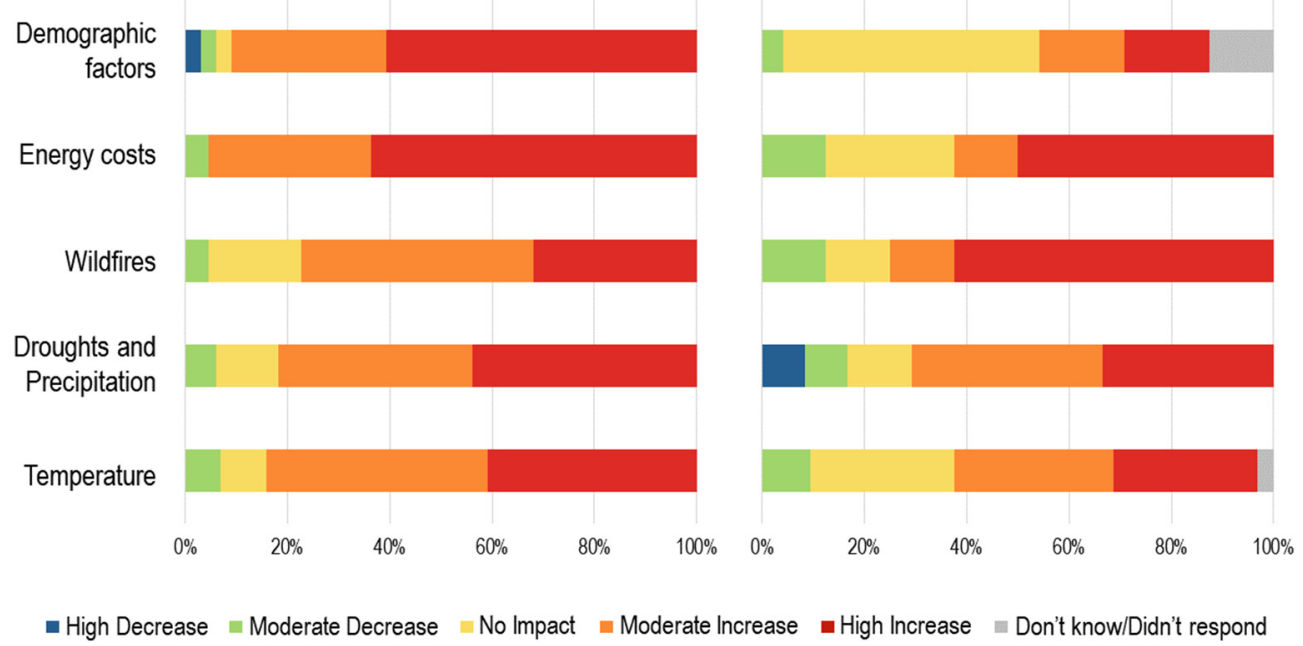

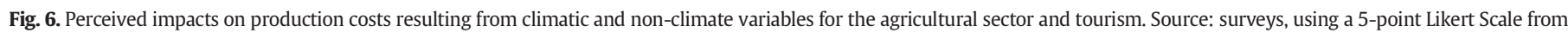
$(-2)$ High Decrease to $(+2)$ High Increase. 
Table 1

Main results and recommendations from future projections (RCP4.5, 2041 to 2070) of the impact of climate change in CIM-TS.

\begin{tabular}{|c|c|c|}
\hline Description & $\begin{array}{l}\text { Main vulnerabilities } \\
\text { (modelled/perceived) }\end{array}$ & Main recommendations \\
\hline \multicolumn{3}{|l|}{ Climate change } \\
\hline Temperature & $\begin{array}{l}\text { Increase in temperatures, } \\
\text { particularly in the summer } \\
\left(+2 \text { to }+3{ }^{\circ} \mathrm{C} \text { ). }\right. \\
\text { Very hot days (maximum } \\
\text { temperature }>25^{\circ} \mathrm{C} \text { ) and } \\
\text { tropical nights }(\text { minimum } \\
\text { temperature }>20{ }^{\circ} \mathrm{C} \text { ) } \\
\text { much more frequent. }\end{array}$ & $\begin{array}{l}\text { Comprehensive approach } \\
\text { and effective coordination } \\
\text { between local, regional } \\
\text { and national entities for } \\
\text { timely and adequate plan- } \\
\text { ning of the response to } \\
\text { heatwaves. } \\
\text { Integration of extreme }\end{array}$ \\
\hline Precipitation & $\begin{array}{l}\text { Decrease in precipitation, } \\
\text { particularly in autumn and } \\
\text { spring. } \\
\text { Extreme isolated precipita- } \\
\text { tion events with stronger } \\
\text { power. }\end{array}$ & $\begin{array}{l}\text { events management (e.g. } \\
\text { heat waves and droughts) } \\
\text { in the territory's interven- } \\
\text { tion plans. }\end{array}$ \\
\hline \multicolumn{3}{|l|}{ Water resources } \\
\hline $\begin{array}{l}\text { Water quality } \\
\text { and quantity }\end{array}$ & $\begin{array}{l}\text { A decrease in daily and } \\
\text { annual flow rates. } \\
\text { Worse water quality (high } \\
\text { concentration of pollut- } \\
\text { ants). } \\
\text { Global reduction in stor- } \\
\text { able water volumes. } \\
\text { Extreme events of high } \\
\text { flows will tend to be less } \\
\text { frequent. }\end{array}$ & $\begin{array}{l}\text { Water management and } \\
\text { planning strategies in the } \\
\text { medium and long term, } \\
\text { extended beyond the terri- } \\
\text { tory. } \\
\text { Mechanisms for water } \\
\text { resources and droughts } \\
\text { monitoring, acting mainly } \\
\text { in terms of prevention. }\end{array}$ \\
\hline \multicolumn{3}{|c|}{ Agriculture and forests } \\
\hline Agriculture & $\begin{array}{l}\text { The favourable period for } \\
\text { most crops will be approx- } \\
\text { imately a month longer. } \\
\text { Higher temperatures and } \\
\text { significantly higher ther- } \\
\text { mal accumulation will } \\
\text { allow generalized anticipa- } \\
\text { tion of all phenological } \\
\text { stages, including fruit rip- } \\
\text { ening. } \\
\text { Reduction of winter cold } \\
\text { conditions (frost days). } \\
\text { The reduction in precipita- } \\
\text { tion will lead to a decrease } \\
\text { in the soil water content } \\
\text { and the availability of } \\
\text { water for irrigation during } \\
\text { summer. }\end{array}$ & $\begin{array}{l}\text { Modifications in various } \\
\text { agricultural practices. } \\
\text { Evaluation of the cultiva- } \\
\text { tion of new agricultural } \\
\text { plant species more } \\
\text { adapted. } \\
\text { More efficiency in water } \\
\text { use and adoption of less } \\
\text { water-demanding produc- } \\
\text { tion systems. }\end{array}$ \\
\hline Viticulture & $\begin{array}{l}\text { Warm temperate/- } \\
\text { temperate regions for viti- } \\
\text { culture will be largely } \\
\text { prevalent. Some high alti- } \\
\text { tude regions will become } \\
\text { suitable for this culture. } \\
\text { A slight decrease in pro- } \\
\text { ductivity in the current } \\
\text { wine regions. } \\
\text { Less exposure to common } \\
\text { diseases, such as downy } \\
\text { mildew, though new dis- } \\
\text { eases or pests may arise } \\
\text { from warmer climates. } \\
\text { To maintain current pro- } \\
\text { ductivity levels, irrigation } \\
\text { needs will increase. }\end{array}$ & \\
\hline Wildfires & $\begin{array}{l}\text { A significant increase in } \\
\text { meteorological fire danger. } \\
\text { Fire regime changes will be } \\
\text { especially noticeable in } \\
\text { more mountainous areas } \\
\text { dominated by open and } \\
\text { flammable vegetation. } \\
\text { In the absence of changes } \\
\text { in fire management } \\
\text { policies, practices and }\end{array}$ & $\begin{array}{l}\text { Integration of the various } \\
\text { components of wildfire } \\
\text { management and its } \\
\text { coherence with land use } \\
\text { planning. } \\
\text { Occupation of the territory } \\
\text { by deciduous forest should } \\
\text { be expanded }\end{array}$ \\
\hline
\end{tabular}

Table 1 (continued)

\begin{tabular}{|c|c|c|}
\hline Description & $\begin{array}{l}\text { Main vulnerabilities } \\
\text { (modelled/perceived) }\end{array}$ & Main recommendations \\
\hline & $\begin{array}{l}\text { vegetation cover, the } \\
\text { annual burnt area is } \\
\text { expected to triple. }\end{array}$ & \\
\hline \multicolumn{3}{|l|}{ Biodiversity } \\
\hline $\begin{array}{l}\text { Flora with } \\
\text { conservation } \\
\text { status }\end{array}$ & $\begin{array}{l}\text { Strong evidence of con- } \\
\text { traction of the climatically } \\
\text { suitable area (potential } \\
\text { distribution) and low sta- } \\
\text { bility of current conditions } \\
\text { for most species, mainly in } \\
\text { mountainous areas in the } \\
\text { eastern region of the terri- } \\
\text { tory. } \\
\text { Several species will main- } \\
\text { tain suitable climatic } \\
\text { conditions, so the preser- } \\
\text { vation of the natural heri- } \\
\text { tage is essential. }\end{array}$ & $\begin{array}{l}\text { Promote models of adap- } \\
\text { tive and climate-smart } \\
\text { management of protected } \\
\text { areas. } \\
\text { Promote active manage- } \\
\text { ment of the most vulnera- } \\
\text { ble species and habitat } \\
\text { types with the greatest } \\
\text { conservation value. }\end{array}$ \\
\hline $\begin{array}{l}\text { Fauna with } \\
\text { conservation } \\
\text { status }\end{array}$ & $\begin{array}{l}\text { More than half of the ana- } \\
\text { lyzed species should expe- } \\
\text { rience moderate or sharp } \\
\text { reductions in suitable cli- } \\
\text { matic areas, mainly in } \\
\text { mountainous areas in the } \\
\text { eastern region of the terri- } \\
\text { tory and, in the majority, } \\
\text { coinciding with the classi- } \\
\text { fied areas of Natura } 2000 \text {. }\end{array}$ & \\
\hline $\begin{array}{l}\text { Invasive alien } \\
\text { species }\end{array}$ & $\begin{array}{l}\text { For most species, the cli- } \\
\text { matically suitable area will } \\
\text { generally remain stable or } \\
\text { increase, in this case } \\
\text { increasing potential con- } \\
\text { flicts with native biodiver- } \\
\text { sity. } \\
\text { The worsening of the inva- } \\
\text { sion phenomena by alien } \\
\text { plants will be particularly } \\
\text { accentuated in mountain } \\
\text { territories located in the } \\
\text { eastern half of the territory } \\
\text { (included in spaces of } \\
\text { Natura 2000). }\end{array}$ & $\begin{array}{l}\text { Implement a program ded- } \\
\text { icated to monitoring, early } \\
\text { detection and support for } \\
\text { the management and con- } \\
\text { trol of invasive species. } \\
\text { Control, confine or eradi- } \\
\text { cate invasive alien species }\end{array}$ \\
\hline \multicolumn{3}{|c|}{ Ecosystem services } \\
\hline $\begin{array}{l}\text { Provisioning } \\
\text { services }\end{array}$ & $\begin{array}{l}\text { Greater vulnerability is } \\
\text { perceived in the produc- } \\
\text { tion of agricultural and } \\
\text { animal food, followed by } \\
\text { the provision of water for } \\
\text { consumption and the pro- } \\
\text { duction of wood (and } \\
\text { derived products). }\end{array}$ & $\begin{array}{l}\text { Evaluate and map the } \\
\text { potential supply of ecosys- } \\
\text { tem services with greater } \\
\text { adaptive significance. } \\
\text { Integrate the impacts of } \\
\text { climate change on biodi- } \\
\text { versity and ecosystem ser- } \\
\text { vices in the elaboration of }\end{array}$ \\
\hline $\begin{array}{c}\text { Regulation } \\
\text { services }\end{array}$ & $\begin{array}{l}\text { Regulatory services seem } \\
\text { to be the most vulnerable } \\
\text { and, therefore the most } \\
\text { perceived to be affected } \\
\text { according to a greater } \\
\text { number of determinants; } \\
\text { Habitat regulation for bio- } \\
\text { diversity stands out as a } \\
\text { service most perceived as } \\
\text { vulnerable (now and in the } \\
\text { future), followed by pro- } \\
\text { tection against fire and soil } \\
\text { erosion, and regulation of } \\
\text { the local climate itself. }\end{array}$ & $\begin{array}{l}\text { land use management } \\
\text { instruments. }\end{array}$ \\
\hline $\begin{array}{l}\text { Cultural } \\
\text { services }\end{array}$ & $\begin{array}{l}\text { Wildfire was the most per- } \\
\text { ceived threat in terms of } \\
\text { affecting the vulnerability } \\
\text { of recreational } \\
\text { opportunities, aesthetic } \\
\text { benefits, spiritual and exis- } \\
\text { tence values. }\end{array}$ & \\
\hline
\end{tabular}


Table 1 (continued)

\begin{tabular}{|c|c|c|}
\hline Description & $\begin{array}{l}\text { Main vulnerabilities } \\
\text { (modelled/perceived) }\end{array}$ & Main recommendations \\
\hline \multicolumn{3}{|l|}{ Socioeconomics } \\
\hline $\begin{array}{l}\text { Climate change } \\
\text { perceptions }\end{array}$ & $\begin{array}{l}\text { Respondents reveal that } \\
\text { climate change is a serious } \\
\text { or very serious problem, } \\
\text { mainly worldwide and } \\
\text { nationally. } \\
\text { At the sectoral level, the } \\
\text { primary sector, followed } \\
\text { by activities related to } \\
\text { tourism (hotels and rural } \\
\text { tourism) are perceived as } \\
\text { the most affected by cli- } \\
\text { mate change. }\end{array}$ & $\begin{array}{l}\text { Adaptation Plan to Demo- } \\
\text { graphic Changes. } \\
\text { System for the Assessment } \\
\text { of Socioeconomic Adapta- } \\
\text { tion. } \\
\text { Study on the responsive- } \\
\text { ness of the existing health } \\
\text { care services to extreme } \\
\text { events. }\end{array}$ \\
\hline $\begin{array}{r}\text { Economic } \\
\text { impacts }\end{array}$ & $\begin{array}{l}\text { In the agricultural sector, } \\
\text { the increase in production } \\
\text { costs can be affected by } \\
\text { energy costs, demographic } \\
\text { factors (associated with an } \\
\text { aging workforce, difficulty } \\
\text { in recruiting young people, } \\
\text { and the need to use immi- } \\
\text { grant labour), and scarcity } \\
\text { of water. } \\
\text { For tourism, climate } \\
\text { change may increase pro- } \\
\text { duction costs due to } \\
\text { energy costs, forest } \\
\text { wildfires, the reduction of } \\
\text { water availability and } \\
\text { extreme precipitation } \\
\text { events. } \\
\text { In the secondary sector, } \\
\text { the energy costs followed } \\
\text { by global demographic fac- } \\
\text { tors are the most perceived } \\
\text { variables that can nega- } \\
\text { tively impact production } \\
\text { costs. }\end{array}$ & \\
\hline \multicolumn{3}{|c|}{ Transversal recommendations } \\
\hline $\begin{array}{l}\text { Information } \\
\text { and } \\
\text { Knowledge }\end{array}$ & $\begin{array}{l}\text { Commission for Climate Change } \\
\text { specific groups by sector. }\end{array}$ & Monitoring and Adaptation and \\
\hline
\end{tabular}

resources, which in turn can also have strong impacts on food security (Ashofteh et al., 2017). As suggested by Golfam et al. (2021), it is important to evaluate water resources management adaptation strategies taking into account water supply and demand of the agricultural sector to

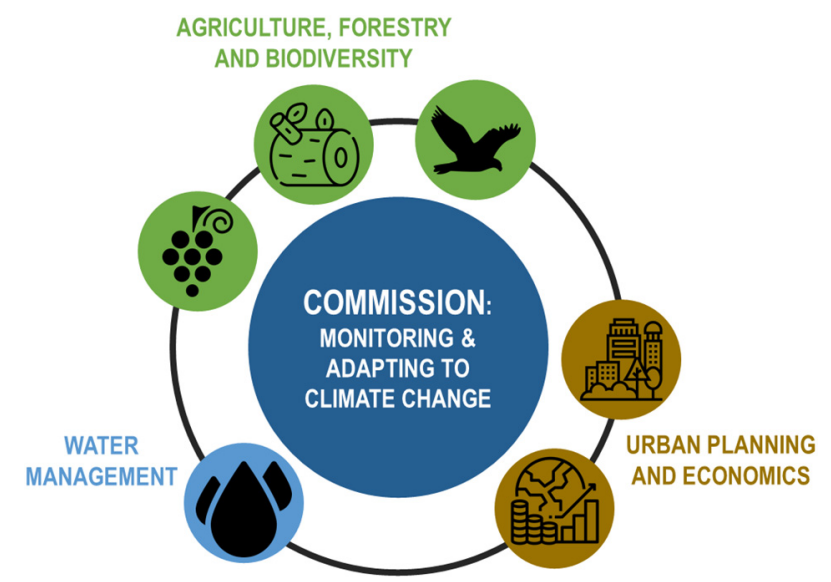

Fig. 7. Proposal of sectoral groups integrating the Commission for Climate Change Monitoring and Adaptation in the CIM-TS. reduce the negative effects of climate change. In addition, low water volumes may compromise the survival of aquatic-dependent species, such as the freshwater pearl mussel (M. margaritifera) (Santos et al., 2015b).

Viticulture is one of the most important activities in the primary sector of the territory, which in turn relates to the secondary sector (e.g. transformation of grape crops into wine) and the tertiary sector (e.g. marketing and sale of wine). A greater aptitude for viticulture in the mountainous regions is expected, at the expense of a reduction in the current regions, possibly causing modifications in terms of wine characteristics and typicity (Fraga et al., 2017). Although the region may be less exposed to common diseases in vines, such as downy mildew, other diseases may arise (Fraga et al., 2017). Adaptation measures may contribute to maintain current productivity levels through smart irrigation systems, changing agricultural practices, and soil management practices (Fraga et al., 2019; Santos et al., 2020).

A future increase in the intensity and frequency of wildfires is expected, leading to a 3-fold increase in burnt area in comparison to the current situation, which is in qualitative agreement with most studies (Dupuy et al., 2020). The wildfire problem in Europe is especially acute in Portugal (Pinto et al., 2018), explaining why they were one of the climate change impacts on ecosystem services perceived as most relevant to the region. Wildfires have in turn consequences at various levels such as for the quality of water resources (Santos et al., 2015a) and ecosystems and biodiversity (Moreno, 2009), therefore adaptation measures are needed to integrate the various components of wildfire management and their coherence with land use management objectives (Moreira et al., 2020).

Many species lose climatic suitability in certain parts of the territory, highlighting the negative effect that climate change can have on vulnerable species. Nonetheless, it is relevant that some of such areas maintain their climate suitability, due to their importance for conservation purposes. As for invasive alien species, their potential area is predicted to expand, increasing the concerns regarding the impacts of these species on local biodiversity and ecosystem functioning. In fact, ecological modelling (in particular, Species Distribution Models), are important tools for prioritization, including both for the conservation of vulnerable species and to control those species that have negative impacts on ecosystems (Guisan et al., 2013; Vicente et al., 2013).

The distribution models for flora and fauna with conservation status did not consider the potential effects of important local threat factors that can generate even more uncertainty, such as changes in land use, landscape fragmentation, and fire regime. Nevertheless, in general, findings indicate that biodiversity can be highly vulnerable to climate change, but a more robust analysis was hindered by scarce knowledge, especially regarding aquatic habitats.

Concerning ecosystem services, the stakeholders' perceptions of climate change impact was in line with studies using biophysical approaches to evaluate the future consequences of climate change (e.g., Carvalho-Santos et al., 2017; Fonseca and Santos, 2019; Fraga et al., 2017). Additionally, cultural services like aesthetic value, spiritual value, and sense of belonging, known to be related to heritage and identity values, were selected by respondents to be impacted by future climate, underlining the importance of considering local knowledge in decision-making processes at regional and local scales (Chan et al., 2012).

One of the main vulnerabilities identified in the socioeconomic characterization was the low educational level of the adult population. This issueis important since the region's ability to find adaptation solutions depends on its human capital endowment, not only in quantity, but fundamentally in its qualification and capacity to absorb and implement innovation that induces investment into more efficient production techniques that are more resilient to climate change (Asante et al., 2012; Bloch et al., 2016).

The analysis of the local perceptions allowed us to conclude that the economic sectors perceived as the most vulnerable to climate change 
are the primary sector and activities related to tourism, although the former is not the sector that generates the largest Gross Value Added in the territory and the latter is not expressive in the region. This aspect may be related to the fact that these sectors are more dependent on climate and ecosystem services compared to the secondary sector. The outcomes from the stakeholder's perceptions also indicate that climate change is perceived as having a lesser impact at the local level than at the national or global levels. This is in line with Nowakowski and Oswald (2020) who concluded that the majority of European citizens are more focused on economic matters that might affect their immediate lives than on climate change issues. Despite the uncertainty associated with the data used in the various models and the outcomes based on stakeholders' perceptions, these results are central to support decision-making.

In general, the results obtained are in line with the IPCC report (IPCC, 2014a), but the effort made to apply the various models to the reality of the territory and the involvement of local stakeholders has made it possible the definition of more refined recommendations.

\subsection{Main lessons from the climate change adaptation planning process}

The workflow diagram in the construction of the Plan included five steps: 1 - Setting the Scene; 2 - Identifying potential impacts and vulnerabilities; 3 - Development of the Adaptation Plan with the main recommendations; 4 - Dissemination; and 5 - Implementation. Some of the main difficulties, challenges and lessons from this process were:

- The lack of consistent databases, models, and the corresponding validation of simulated results for all sectors studied. Meteorological data for the territory was lacking, as well as structures for information management and sharing. To overcome this difficulty, in the case of biodiversity and water resources, the data available in the territory did not allow for the calibration of any type of model. As such, data with at the national scale had to be used to calibrate models that were then projected for the territory;

- From the initial phase of the project the team realized that the climate projections that were used in projects such as ClimAdaPT.Local, were not suitable for the scale of this study, since these projections considered the territory as uniform, not capturing its heterogeneity. As such, proper datasets had to be developed to be used at this scale of planning, based on previous studies of the team;

- Adaptation planning should involve a multidisciplinary team including social and natural scientists and political and economic agents working in a collaborative and integrated way. The diversity of visions on the part of the multidisciplinary team, with very different experiences and scientific knowledge, creates difficulties. To promote collaboration and interaction between the various stakeholders, it was important to engage them in all steps of the study to create a greater sense of ownership and to define common goals, which in turn can lead to greater success of projects, as highlighted by Wamsler (2017). The fact that all the teams have already worked in the territory also contributed to a more effective collaboration;

- The interface between science and local stakeholders was a great challenge, in particular the mobilization to participate in the workshops. As the discussion of climate change is a new issue in the scale of the study, it was necessary to continuously make a clarification exercise to the local stakeholders. The results of the questionnaires indicate that stakeholders perceive the climate change phenomenon essentially as a global rather than a local problem, which may have contributed to the difficulty of their mobilization and participation. This may also be related to the fact that smaller municipalities, generally with fewer resources, may have less information and capacity to respond to these challenges (Amundsen et al., 2010; Campos et al., 2017; Rauken et al., 2015). As such, a great effort was made to building the capacity of local stakeholders and disseminating the results of the study. However, more time would be needed to raise awareness of other municipal representatives and technicians on the importance of this phenomenon at the local scale.

- Perceptions about the impacts of climate change depend on the socioeconomic context. Since these perceptions can influence adaptation responses, it is important to consider them from an early stage of the study (Campos et al., 2017). Additionally, risks associated with extreme climatic events, and the effectiveness of adaptation measures can also be influenced by non-climatic aspects, such as demographic changes (Füssel, 2007; Moser and Boykoff, 2013).

- The creation of a Commission for Climate Change Monitoring and Adaptation was one of the main recommendations. However, coordination at the CIM-TS level may be insufficient, since many ecological systems and socioeconomic processes affect (or are affected by) other geographic scales (Adger et al., 2005; Lundqvist, 2016), such as the Tâmega and Sousa river basins, natural reserves, or forest areas. Thus, concerted decisions must be taken between the array of local agents and regional and national agencies. Accomplishing adaptation actions on the territory is a matter of decision within the political sphere, thus the implementation of this plan is highly dependent on political will. Other limiting factors are the lack of financial resources, technical competencies, and awareness of the problem (Füssel, 2007).

\subsection{Final remarks}

The atmospheric variables obtained from climate projections were used as input to other models, particularly in the calculation of various indices of extremes and bioclimatic indices, and in simulations of water resources, burnt areas and potentially threatened species of flora and fauna and the expansion of invasive species in the territory.

After defining the common future climate scenario, each team worked on the models of each scientific area. The team considered that it would not be possible, in this study, to integrate the results obtained between the different sectors since these would have to be explicit in spatial terms and the results obtained in each model have uncertainties that when integrated could result in strong bias and propagation errors.

The results of the climate projections and simulations of each scientific area were used as a basis for discussion with local stakeholders through workshops to reflect on which ecosystem services and dimensions of economic activity will be most affected. The results obtained in these workshops allowed some adjustments to the outputs of simulation models.

Based on the results of scientific models and the know-how of local stakeholders, several adaptation measures were proposed. In the final phase of the study, the impact that these measures would have on the other sectors were discussed by the multidisciplinary team. This was an initial exercise, carried out among the various members of the project team.

Although the models that each team used to make their own sectoral assessment are independent, we consider they complement each other. The effort of the multidisciplinary team in holding several meetings from an early stage of the study to take methodological decisions, contributed to greater coherence and integration of the analyses. Some of the most important decisions were to use of the same climate conditions and projections, the definition of adaptation measures based on the final outputs of the models and the know-how of stakeholders and the evaluation of the measures based on the effects on the other sectors.

Future work to improve the present study should include field data collection to allow a better harmonisation and to work with more realistic scenarios. In terms of modelling, the next steps of this study must also include the development of specific models for each sector for a deeper assessment of the impacts of climate change and regional vulnerability. 
Some proposals for future work refer to the detailed study of groundwater reserves and the risk of contamination of surface and groundwater, of the wine sector but also in other emergent crops in the territory and the evaluation of flooding in the urban network. We also highlight the need to deepen the assessments in other themes that due to budget limitations were evaluated more superficially during the discussions of the multidisciplinary team mainly human health and mobility.

This study presents several recommendations of adaptation measures for the various sectors, but it is necessary to develop studies to support policy makers in terms of prioritization of sectors and measures, weighing the potential reduction of negative effects of climate and the associated economic costs.

In addition, we agree with the need to increase integration between the various themes and to explore the synergistic effects of various drivers. For example, the direct effects of climate change on biodiversity were assessed, however climate change also has a direct impact on other processes such as land use changes and increased occurrence of fires, which in turn can have additional effects on biodiversity. Therefore, in the future, more efforts should be made to increase the integration of the various outputs. Integration of models exploring different indicators can be explored using simulations platforms such as INVEST (Nelson et al., 2009), which is used in the evaluation of multiple ecosystem services and includes several models from different fields such as biodiversity, soil protection, carbon sequestration for climate regulation, water resources, among others.

The results of the present study contribute to a greater understanding of climate change impacts in a mountainous inter-municipal community in southern Europe in different sectors and systems, namely water resources, agriculture, forests, biodiversity, and socioeconomy. The lessons learned can support plans and strategies for local adaptation, namely through the integration of scientific research and participatory approaches.

Supplementary data to this article can be found online at https://doi. org/10.1016/j.scitotenv.2021.150320.

\section{CRediT authorship contribution statement}

Catarina Gonçalves: Conceptualization, Methodology, Formal analysis, Investigation, Writing - original draft, Writing - review \& editing, Visualization. João P. Honrado: Conceptualization, Methodology, Formal analysis, Investigation, Writing - review \& editing, Visualization. João Cerejeira: Conceptualization, Methodology, Formal analysis, Investigation, Writing - review \& editing, Visualization. Rita Sousa: Conceptualization, Methodology, Formal analysis, Investigation, Writing - review \& editing, Visualization. Paulo M. Fernandes: Conceptualization, Methodology, Formal analysis, Investigation, Writing review \& editing, Visualization. Ana Sofia Vaz: Conceptualization, Methodology, Formal analysis, Investigation, Writing - review \& editing, Visualization. Manuela Alves: Conceptualization, Investigation. Miguel Araújo: Conceptualization, Methodology, Formal analysis, Investigation, Visualization. Cláudia Carvalho-Santos: Conceptualization, Methodology, Formal analysis, Investigation, Writing - review \& editing, Visualization. André Fonseca: Conceptualization, Methodology, Formal analysis, Investigation, Writing - review \& editing, Visualization. Hélder Fraga: Conceptualization, Methodology, Formal analysis, Investigation, Writing - review \& editing, Visualization. João F. Gonçalves: Conceptualization, Methodology, Formal analysis, Investigation, Writing - review \& editing, Visualization. Angela Lomba: Conceptualization, Methodology, Formal analysis, Investigation, Writing - review \& editing, Visualization. Eva Pinto: Conceptualization, Methodology, Formal analysis, Investigation, Writing - review \& editing, Visualization. Joana R. Vicente: Conceptualization, Methodology, Formal analysis, Investigation, Writing - review \& editing, Visualization. João A. Santos: Conceptualization, Methodology, Formal analysis, Investigation, Writing - review \& editing, Visualization, Project administration.

\section{Declaration of competing interest}

The authors declare that they have no known competing financial interests or personal relationships that could have appeared to influence the work reported in this paper.

\section{Acknowledgements}

This research was conducted within the framework of a project funded by POSEUR (Programa Operacional Sustentabilidade e Eficiência no Uso de Recursos, Portugal 2020, POSEUR-08-201674), promoted by the CIM-TS (Comunidade Intermunicipal do Tâmega e Sousa) and undertaken by a consortium coordinated by IDARN (Instituto para o Desenvolvimento Agrário da Região Norte), with the participation of UTAD (Universidade de Trás-os-Montes e Alto douro), UP (Universidade do Porto) and UM (Universidade do Minho). This work was supported by National Funds by FCT Portuguese Foundation for Science and Technology, under the project UIDB/04033/2020 and UIDB/03182/2020. AS Vaz was supported by Ministerio de Ciencia, Innovación y Universidades (Spain) through the 2018 Juan de la Cierva-Formación program [contract reference FJC2018-038131-I]. AL was supported by national funds through FCT - Foundation for Science and Technology, I.P., in the context of the Transitory Norm - DL57/2016/CP1440/ CT0001.

\section{References}

Adger, W.N., Arnell, N.W., Tompkins, E.L., 2005. Successful adaptation to climate change across scales. Glob. Environ. Chang. 15, 77-86. https://doi.org/10.1016/j.gloenvcha. 2004.12.005.

Aguiar, F.C., Bentz, J., Silva, J.M.N., Fonseca, A.L., Swart, R., Santos, F.D., Penha-Lopes, G., 2018. Adaptation to climate change at local level in Europe: an overview. Environ. Sci. Policy 86, 38-63. https://doi.org/10.1016/j.envsci.2018.04.010.

Amundsen, H., Berglund, F., Westskog, H., 2010. Overcoming barriers to climate change adaptation-a question of multilevel governance? Environ. Plan. C Gov. Policy 28, 276-289. https://doi.org/10.1068/c0941.

Andrade, C., Fraga, H., Santos, J.A., 2014. Climate change multi-model projections for temperature extremes in Portugal. Atmos. Sci. Lett. 15, 149-156. https://doi.org/10.1002/ asl2.485.

Andrews, P.L., 2014. Current status and future needs of the BehavePlus Fire Modeling System. Int. J. Wildl. Fire 23, 21-33. https://doi.org/10.1071/WF12167.

Araújo, M.B., Alagador, D., Cabeza, M., Nogués-Bravo, D., Thuiller, W., 2011. Climate change threatens European conservation areas. Ecol. Lett. 14, 484-492. https://doi. org/10.1111/j.1461-0248.2011.01610.x.

Asante, F.A., Boakye, A.A., Egyir, I.S., Jatoe, J.B.D., 2012. Climate change and farmers' adaptive capacity to strategic innovations: the case of northern Ghana. Int. J. Dev. Sustain. 1, 766-784.

Ashofteh, P.S., Bozorg-Haddad, O., Loáiciga, H.A., 2017. Impacts of climate change on the conflict between water resources and agricultural water use. J. Irrig. Drain. Eng. 143 (4), 02516002. https://doi.org/10.1061/(ASCE)IR.1943-4774.0001143.

Beck, J., Böller, M., Erhardt, A., Schwanghart, W., 2014. Spatial bias in the GBIF database and its effect on modeling species' geographic distributions. Ecol. Inform. 19, 10-15. https://doi.org/10.1016/j.ecoinf.2013.11.002.

Bicknell, B.R., Imhoff, J.C., Kittle Jr., J.L., Jobes, T.H., Donigian Jr., A.S., Johanson, R., 2001. Hydrological Simulation Program-Fortran: HSPF Version 12 User's Manual. AQUA TERRA Consultants, Mountain View, California, USA.

Bloch, R., Knierim, A., Häring, A.M., Bachinger, J., 2016. Increasing the adaptive capacity of organic farming systems in the face of climate change using action research methods. Org. Agric. 6, 139-151. https://doi.org/10.1007/s13165-015-0123-5.

Campos, I., Guerra, J., Ferreira, J.G., Schmidt, L., Alves, F., Vizinho, A., Lopes, G.P., 2017. Understanding climate change policy and action in portuguese municipalities: a survey. Land Use Policy 62, 68-78. https://doi.org/10.1016/j.landusepol.2016.12.015.

Carvalho-Santos, C., Monteiro, A.T., Azevedo, J.C., Honrado, J.P., Nunes, J.P., 2017. Climate change impacts on water resources and reservoir management: uncertainty and adaptation for a mountain catchment in Northeast Portugal. Water Resour. Manag. 31, 3355-3370. https://doi.org/10.1007/s11269-017-1672-z.

Chan, K.M.A., Guerry, A.D., Balvanera, P., Klain, S., Satterfield, T., Basurto, X., Bostrom, A., Chuenpagdee, R., Gould, R., Halpern, B.S., Hannahs, N., Levine, J., Norton, B., Ruckelshaus, M., Russell, R., Tam, J., Woodside, U., 2012. Where are cultural and social in ecosystem services? A framework for constructive engagement. Bioscience 62 , 744-756. https://doi.org/10.1525/bio.2012.62.8.7.

Coelho, S., Rafael, S., Coutinho, M., Monteiro, A., Medina, J., Figueiredo, S., Cunha, S., Lopes, M., Miranda, A.I., Borrego, C., 2020. Climate-change adaptation framework for multiple urban areas in Northern Portugal. Environ. Manag. 66, 395-406. https://doi.org/ 10.1007/s00267-020-01313-5. 
Costa, R., Fraga, H., Fernandes, P.M., Santos, J.A., 2017. Implications of future bioclimatic shifts on Portuguese forests. Reg. Environ. Chang. 17, 117-127. https://doi.org/10. 1007/s10113-016-0980-9.

Dannevig, H., Rauken, T., Hovelsrud, G., 2012. Implementing adaptation to climate change at the local level. Local Environ. 17, 597-611. https://doi.org/10.1080/13549839. 2012.678317

Dupuy, J.luc, Fargeon, H., Martin-StPaul, N., Pimont, F., Ruffault, J., Guijarro, M., Hernando, C., Madrigal, J., Fernandes, P., 2020. Climate change impact on future wildfire danger and activity in southern Europe: a review. Ann. For. Sci. https://doi.org/10.1007/ s13595-020-00933-5.

Eurostat, 2018. Regions in the European Union. Nomenclature of Territorial Units for Statistics- NUTS 2016/EU-28: Edition 2018. Publications Office of the European Union, Luxembourg https://doi.org/10.2785/475524.

Fernandes, P.M., Barros, A.M.G., Pinto, A., Santos, J.A., 2016. Characteristics and controls of extremely large wildfires in the western Mediterranean Basin. J. Geophys. Res. Biogeosci. 121, 2141-2157. https://doi.org/10.1002/2016JG003389.

Fonseca, A.R., Santos, J.A., 2018. High-resolution temperature datasets in Portugal from a geostatistical approach: variability and extremes. J. Appl. Meteorol. Climatol. 57, 627-644. https://doi.org/10.1175/JAMC-D-17-0215.1.

Fonseca, A.R., Santos, J.A., 2019. Predicting hydrologic flows under climate change: the Tâmega Basin as an analog for the Mediterranean region. Sci. Total Environ. 668, 1013-1024. https://doi.org/10.1016/j.scitotenv.2019.01.435.

Fraga, H., Costa, R., Moutinho-Pereira, J., Correia, C.M., Dinis, L.T., Gonçalves, I., Silvestre, J., Eiras-Dias, J., Malheiro, A.C., Santos, J.A., 2015. Modeling phenology, water status, and yield components of three Portuguese grapevines using the STICS crop model. Am. J. Enol. Vitic. 66, 482-491. https://doi.org/10.5344/ajev.2015.15031.

Fraga, H., de Cortázar, García, Atauri, I., Malheiro, A.C., Moutinho-Pereira, J., Santos, J.A. 2017. Viticulture in Portugal: a review of recent trends and climate change projections. OENO One 51, 61-69. https://doi.org/10.20870/oeno-one.2017.51.2.1621.

Fraga, H., Pinto, J.G., Santos, J.A., 2019. Climate change projections for chilling and heat forcing conditions in European vineyards and olive orchards: a multi-model assessment. Clim. Chang. 152, 179-193. https://doi.org/10.1007/s10584-018-2337-5.

Fraga, H., Molitor, D., Leolini, L., Santos, J.A., 2020a. What is the impact of heatwaves on European viticulture? A modelling assessment. Appl. Sci. 10, 3030. https://doi.org/ 10.3390/app10093030.

Fraga, H., Pinto, J.G., Santos, J.A., 2020b. Olive tree irrigation as a climate change adaptation measure in Alentejo, Portugal. Agric. Water Manag. 237, 106193. https://doi. org/10.1016/j.agwat.2020.106193.

Fraga, H., Pinto, J.G., Viola, F., Santos, J.A., 2020c. Climate change projections for olive yields in the Mediterranean Basin. Int. J. Climatol. 40, 769-781. https://doi.org/10. 1002/joc.6237.

Füssel, H.M., 2007. Adaptation planning for climate change: concepts, assessment approaches, and key lessons. Sustain. Sci. https://doi.org/10.1007/s11625-007-0032-y.

Gallien, L., Douzet, R., Pratte, S., Zimmermann, N.E., Thuiller, W., 2012. Invasive species distribution models - how violating the equilibrium assumption can create new insights. Glob. Ecol. Biogeogr. 21, 1126-1136. https://doi.org/10.1111/j.1466-8238. 2012.00768.x.

Golfam, P., Ashofteh, P.S., Loáiciga, H.A., 2021. Modeling adaptation policies to increase the synergies of the water-climate-agriculture nexus under climate change. Environ. Dev. 37, 100612. https://doi.org/10.1016/j.envdev.2021.100612.

Gonçalves, J., Honrado, J.P., Vicente, J.R., Civantos, E., 2016. A model-based framework for assessing the vulnerability of low dispersal vertebrates to landscape fragmentation under environmental change. Ecol. Complex. 28, 174-186. https://doi.org/10.1016/j. ecocom.2016.05.003.

Guisan, A., Tingley, R., Baumgartner, J.B., Naujokaitis-Lewis, I., Sutcliffe, P.R., Tulloch, A.I.T., Regan, T.J., Brotons, L., McDonald-Madden, E., Mantyka-Pringle, C., Martin, T.G., Rhodes, J.R., Maggini, R., Setterfield, S.A., Elith, J., Schwartz, M.W., Wintle, B.A., Broennimann, O., Austin, M., Ferrier, S., Kearney, M.R., Possingham, H.P., Buckley, Y.M., 2013. Predicting species distributions for conservation decisions. Ecol. Lett. 16, 1424-1435. https://doi.org/10.1111/ele.12189.

Hagen, B., Middel, A., Pijawka, D., 2016. European climate change perceptions: public support for mitigation and adaptation policies. Environ. Policy Gov. 26, 170-183. https:// doi.org/10.1002/eet.1701.

Huggel, C., Scheel, M., Albrecht, F., Andres, N., Calanca, P., Jurt, C., Khabarov, N., MiraSalama, D., Rohrer, M., Salzmann, N., Silva, Y., Silvestre, E., Vicuña, L., Zappa, M., 2015. A framework for the science contribution in climate adaptation: experiences from science-policy processes in the Andes. Environ. Sci. Policy 47, 80-94. https:// doi.org/10.1016/j.envsci.2014.11.007.

INE, 2018a. Estatísticas Demográficas 2017. Instituto Nacional de Estatísticas, I. P., Lisboa.

INE, 2018b. Anuário Estatístico da Região Norte 2017. Instituto Nacional de Estatísticas, I. P., Lisboa.

INE, 2019. Contas regionais - SEC2010, base 2016. Instituto Nacional de Estatísticas, I. P., Lisboa.

IPCC, 2014a. In: Barros, V.R., Field, C.B., Dokken, D.J., Mastrandrea, M.D., Mach, K.J., Bilir, T.E., Chatterjee, M., Ebi, K.L., Estrada, Y.O., Genova, R.C., Girma, B., Kissel, E.S., Levy, A.N., MacCracken, S., Mastrandrea, P.R., White, L.L. (Eds.), Climate Change 2014: Impacts, Adaptation, and Vulnerability. Part B: Regional Aspects. Contribution of Working Group II to the Fifth Assessment Report of the Intergovernmental Panel on Climate Change. Cambridge University Press, Cambridge, United Kingdom and New York, NY, USA, p. 688

IPCC, 2014b. Summary for policymakers. In: Field, C.B., Barros, V.R., Dokken, D.J., Mach, K.J., Mastrandrea, M.D., Bilir, T.E., Chatterjee, M., Ebi, K.L., Estrada, Y.O., Genova, R.C., Girma, B., Kissel, E.S., Levy, A.N., MacCracken, S., Mastrandrea, P.R., White, L.L. (Eds.), Climate Change 2014: Impacts, Adaptation, and Vulnerability. Part A: Global and Sectoral Aspects. Contribution of Working Group II to the Fifth Assessment
Report of the Intergovernmental Panel on Climate Change. Cambridge University Press, Cambridge, United Kingdom and New York, NY, USA, pp. 1-32.

IPCC, 2014c. In: Core Writing Team, Pachauri, R.K., Meyer, L.A. (Eds.), Climate Change 2014: Synthesis Report. Contribution of Working Groups I, II and III to the Fifth Assessment Report of the Intergovernmental Panel on Climate Change. IPCC, Geneva, Switzerland, p. 151.

IPCC, 2018. Summary for policymakers. In: Masson-Delmotte, V., Zhai, P., Pörtner, H.-O., Roberts, D., Skea, J., Shukla, P.R., Pirani, A., Moufouma-Okia, W., Péan, C., Pidcock, R., Connors, S., Matthews, J.B.R., Chen, Y., Zhou, X., Gomis, M.I., Lonnoy, E., Maycock, T., Tignor, M., Waterfield, T. (Eds.), Global Warming of $1.5^{\circ} \mathrm{C}$. An IPCC Special Report on the Impacts of Global Warming of $1.5^{\circ} \mathrm{C}$ Above Pre-industrial Levels and Related Global Greenhouse Gas Emission Pathways, in the Context of Strengthening the Global Response to the Threat of Climate Change, Sustainable Development, and Efforts to Eradicate Poverty . https://www.ipcc.ch/sr15/.

Karl, T.R., Nicholls, N., Ghazi, A., 1999. Clivar/GCOS/WMO workshop on indices and indicators for climate extremes workshop summary. Clim. Chang. 42, 3-7. https://doi. org/10.1023/A:1005491526870.

Ker Rault, P.A., Koundouri, P., Akinsete, E., Ludwig R., Huber-Garcia, V., Tsani, S., Acuna, V Kalogianni, E., Luttik, J., Kok, K., Skoulikidis, N., Froebrick, J., 2019. Down scaling of climate change scenarii to river basin level: a transdisciplinary methodology applied to Evrotas river basin, Greece. Sci. Total Environ. 660, 1623-1632. https://doi.org/10. 1016/j.scitotenv.2018.12.369.

Lemieux, C.J., Gray, P.A., Douglas, A.G., Nielsen, G., Pearson, D., 2014. From science to policy: the making of a watershed-scale climate change adaptation strategy. Environ. Sci. Policy 42, 123-137. https://doi.org/10.1016/j.envsci.2014.06.004.

Lundqvist, L.J., 2016. Planning for climate change adaptation in a multi-level context: the Gothenburg metropolitan area. Eur. Plan. Stud. 24, 1-20. https://doi.org/10.1080/ 09654313.2015.1056774.

Moreira, F., Ascoli, D., Safford, H., Adams, M.A., Moreno, J.M., Pereira, J.M.C., Catry, F.X., Armesto, J., Bond, W., González, M.E., Curt, T., Koutsias, N., McCaw, L., Price, O., Pausas, J.G., Rigolot, E., Stephens, S., Tavsanoglu, C., Vallejo, V.R., Van Wilgen, B.W., Xanthopoulos, G., Fernandes, P.M., 2020. Wildfire management in Mediterraneantype regions: paradigm change needed. Environ. Res. Lett. https://doi.org/10.1088/ 1748-9326/ab541e.

Moreno, J.M., 2009. Impacts on potential wildfire risk due to changes in climate. In: Birot, Y. (Ed.), Living With Wildfires: What Science Can Tell Us. European Forest Institute, Joensuu, Finland, p. 82.

Moser, S.C., Boykoff, M.T. (Eds.), 2013. Successful Adaptation to Climate Change: Linking Science and Policy in a Rapidly Changing World, first ed. Routledge.

Moss, R.H., Edmonds, J.A., Hibbard, K.A., Manning, M.R., Rose, S.K., Van Vuuren, D.P. Carter, T.R., Emori, S., Kainuma, M., Kram, T., Meehl, G.A., Mitchell, J.F.B., Nakicenovic, N., Riahi, K., Smith, S.J., Stouffer, R.J., Thomson, A.M., Weyant, J.P., Wilbanks, T.J., 2010. The next generation of scenarios for climate change research and assessment. Nature 463, 747-756. https://doi.org/10.1038/nature08823.

Mukheibir, P., Kuruppu, N., Gero, A., Herriman, J., 2013. Overcoming cross-scale challenges to climate change adaptation for local government: a focus on Australia. Clim. Chang. 121, 271-283. https://doi.org/10.1007/s10584-013-0880-7.

Nelson, E., Mendoza, G., Regetz, J., Polasky, S., Tallis, H., Cameron, D., Chan, K., Daily, G. Goldstein, J., Kareiva, P., Lonsdorf, E., Naidoo, R., Ricketts, T., Shaw, M., 2009. Modeling multiple ecosystem services, biodiversity conservation, commodity production, and tradeoffs at landscape scales. Front. Ecol. Environ. 7, 4-11. https://doi.org/10.1890/ 080023.

Nowakowski, A., Oswald, A.J., 2020. Do Europeans Care about Climate Change? An Illustration of the Importance of Data on Human Feelings. IZA Discuss. Pap. No. 13660.

Pinto, M.M., DaCamara, C.C., Trigo, I.F., Trigo, R.M., Turkman, K.F., 2018. Fire danger rating over Mediterranean Europe based on fire radiative power derived from Meteosat. Nat. Hazards Earth Syst. Sci. 18, 515-529. https://doi.org/10.5194/nhess-18-5152018.

Pittman, J., Wittrock, V., Kulshreshtha, S., Wheaton, E., 2011. Vulnerability to climate change in rural Saskatchewan: case study of the rural municipality of Rudy No. 284. J. Rural. Stud. 27, 83-94. https://doi.org/10.1016/j.jrurstud.2010.07.004.

Pohl, C., 2005. Transdisciplinary collaboration in environmental research. Futures 37, 1159-1178. https://doi.org/10.1016/j.futures.2005.02.009.

Pordata - Base de Dados de Portugal, 2011. Densidade Populacional - Número Médio de Indivíduos por km2 por NUTS III. Fundação Francisco Manuel dos Santos, Lisboa.

Pordata - Base de Dados de Portugal, 2019. Superfície do território em Km2 por NUTS III. Fundação Francisco Manuel dos Santos, Lisboa.

Rauken, T., Mydske, P.K., Winsvold, M., 2015. Mainstreaming climate change adaptation at the local level. Local Environ. 20, 408-423. https://doi.org/10.1080/13549839. 2014.880412.

Resolution of the Council of Ministers nr. 56/2015, 30 July. Diário da República n. ${ }^{\circ}$ 147-1로 série.

Santos, R.M.B., Sanches Fernandes, L.F., Pereira, M.G., Cortes, R.M.V., Pacheco, F.A.L., 2015a Water resources planning for a river basin with recurrent wildfires. Sci. Total Environ. 526, 1-13. https://doi.org/10.1016/j.scitotenv.2015.04.058.

Santos, R.M.B., Sanches Fernandes, L.F., Varandas, S.G.P., Pereira, M.G., Sousa, R., Teixeira, A., Lopes-Lima, M., Cortes, R.M.V., Pacheco, F.A.L., 2015b. Impacts of climate change and land-use scenarios on Margaritifera margaritifera, an environmental indicator and endangered species. Sci. Total Environ. 511, 477-488. https://doi.org/10.1016/j. scitotenv.2014.12.090.

Santos, M., Fonseca, A., Fragoso, M., Santos, J.A., 2019a. Recent and future changes of precipitation extremes in mainland Portugal. Theor. Appl. Climatol. 137, 1305-1319. https://doi.org/10.1007/s00704-018-2667-2.

Santos, M., Fraga, H., Belo-Pereira, M., Santos, J.A., 2019b. Assessment of growing thermal conditions of main fruit species in Portugal based on hourly records from a Weather Station Network. Appl. Sci. 9, 3782. https://doi.org/10.3390/app9183782. 
Santos, J.A., Fraga, H., Malheiro, A.C., Moutinho-Pereira, J., Dinis, L.-T., Correia, C. Moriondo, M., Leolini, L., Dibari, C., Costafreda-Aumedes, S., Kartschall, T., Menz, C., Molitor, D., Junk, J., Beyer, M., Schultz, H.R., 2020. A review of the potential climate change impacts and adaptation options for European viticulture. Appl. Sci. 10, 3092. https://doi.org/10.3390/app10093092.

Schmidt, L., Alves, A.F., Valente, S., Mourato, J.M., 2018. Outlining community perceptions of climate change in local adaptation strategies development: the case of ClimAdaPT. Local. In: Alves, F., Leal Filho, W., Azeiteiro, U. (Eds.), Theory and Practice of Climate Adaptation. Climate Change Management. Springer, Cham, pp. 219-233 https://doi. org/10.1007/978-3-319-72874-2_13.

Stocks, B.J., Lynham, T.J., Lawson, B.D., Alexander, M.E., Wagner, C.E.Van, McAlpine, R.S., Dubé, D.E., 1989. The Canadian forest fire danger rating system: an overview. For. Chron. 65, 450-457. https://doi.org/10.5558/tfc65450-6.

Thuiller, W., Lafourcade, B., Engler, R., Araújo, M.B., 2009. BIOMOD - a platform for ensemble forecasting of species distributions. Ecography 32, 369-373. https://doi.org/10. 1111/j.1600-0587.2008.05742.x.
Thuiller, W., Georges, D., Engler, R., 2014. biomod2: ensemble platform for species distribution modeling, R package version 3.1-48. URL http://CRAN.R-project.org/package= biomod2.

Vicente, J.R., Fernandes, R.F., Randin, C.F., Broennimann, O., Gonçalves, J., Marcos, B., Pôças, I., Alves, P., Guisan, A., Honrado, J.P., 2013. Will climate change drive alien invasive plants into areas of high protection value? An improved model-based regional assessment to prioritise the management of invasions. J. Environ. Manag. 131, 185-195. https://doi.org/10.1016/j.jenvman.2013.09.032.

Wamsler, C., 2017. Stakeholder involvement in strategic adaptation planning: transdisciplinarity and co-production at stake? Environ. Sci. Policy 75, 148-157. https://doi.org/10.1016/j.envsci.2017.03.016.

Whitehead, P.G., Jin, L., Bussi, G., Voepel, H.E., Darby, S.E., Vasilopoulos, G., Manley, R. Rodda, H., Hutton, C., Hackney, C., Tri, V.P.D., Hung, N.N., 2019. Water quality modelling of the Mekong River basin: climate change and socioeconomics drive flow and nutrient flux changes to the Mekong Delta. Sci. Total Environ. 673, 218-229. https://doi.org/10.1016/j.scitotenv.2019.03.315. 